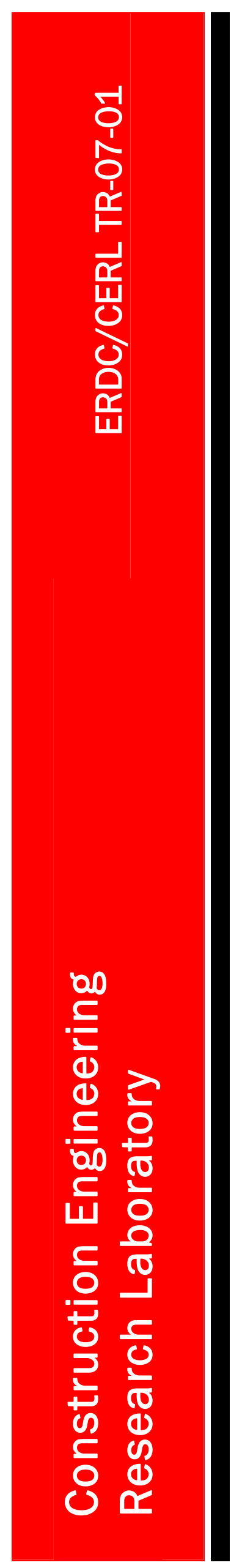

\title{
Habitat Selection by the Gopher Tortoise (Gopherus polyphemus)
}

\section{US Army Corps of Engineers ${ }_{\circledast}$}

Engineer Research and Development Center

Tracey D. Tuberville, Kurt A. Buhlmann, Harold E. Balbach,

March 2007

Stephen H. Bennett, John P. Nestor, J.W. Gibbons, and R.R. Sharitz

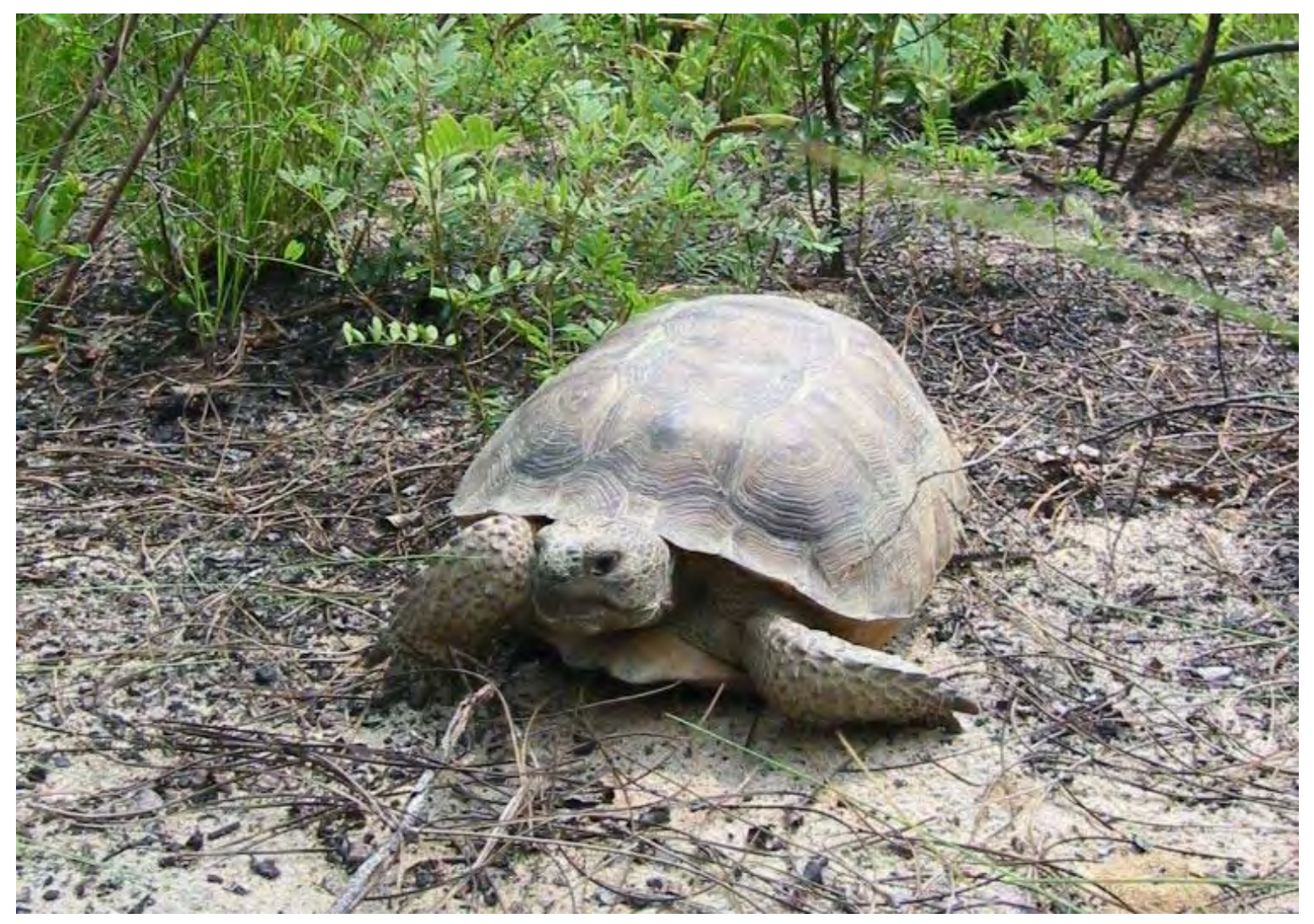




\title{
Habitat Selection by the Gopher Tortoise (Gopherus polyphemus)
}

\author{
Tracey D. Tuberville \\ University of Georgia's Savannah River Ecology Laboratory \\ P.O. Drawer E \\ Aiken, SC 29802 \\ Harold E. Balbach \\ Construction Engineering Research Laboratory \\ U.S. Army Engineer Research and Development Center \\ P.O. Box 9005 \\ Champaign, IL 61826-9005 \\ Contributing authors: \\ Kurt A. Buhlmann, University of Georgia, SREL and South Carolina DNR \\ Stephen H. Bennett, South Carolina DNR \\ John P. Nestor, University of Georgia, SREL \\ J.W. Gibbons, University of Georgia, SREL \\ R. R. Sharitz, University of Georgia, SREL
}

Final report

Approved for public release; distribution is unlimited.

Prepared for U.S. Army Corps of Engineers

Under Work Unit CNN-T063 


\begin{abstract}
The gopher tortoise (Gopherus polyphemus) occurs in the southeastern Coastal Plain and has experienced widespread decline due to habitat loss and other human impacts. The largest remaining populations occur on private lands and military installations. Proper management at these sites will be critical to the success of the species. The goal of this study was to determine the response of gopher tortoises to forestry management practices commonly implemented in the management of the redcockaded woodpecker. We monitored habitat use of individual tortoises at four study sites with different ownership and management scenarios: Fort Gordon (military installation, winter burning), Savannah River Site (federal defense facility, winter burning, translocated population), Tillman Sand Ridge (state wildlife preserve, summer burning), and a private hunting preserve (no management). Habitat data were collected to characterize typical canopy and herbaceous vegetation of each site. Data were collected at active burrows; the anecdotal belief that tortoises select the most open habitat available was confirmed. The preferred habitat density appears to be in the range of 40 percent canopy cover, a value compatible with current woodpecker management guidelines. Results will be used to develop recommendations for the concurrent management of gopher tortoises and red-cockaded woodpeckers.
\end{abstract}

DISCLAIMER: The contents of this report are not to be used for advertising, publication, or promotional purposes. Citation of trade names does not constitute an official endorsement or approval of the use of such commercial products. All product names and trademarks cited are the property of their respective owners. The findings of this report are not to be construed as an official Department of the Army position unless so designated by other authorized documents. 


\section{Contents}

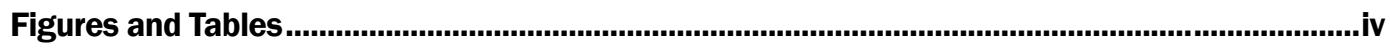

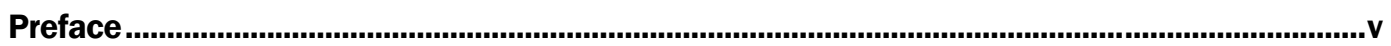

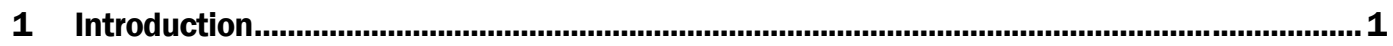

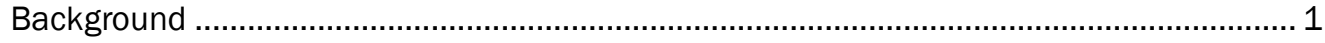

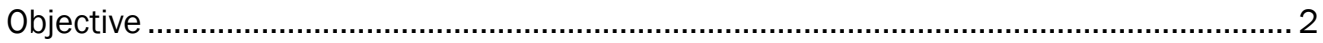

Scope

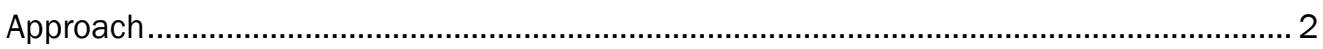

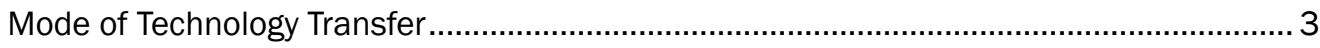

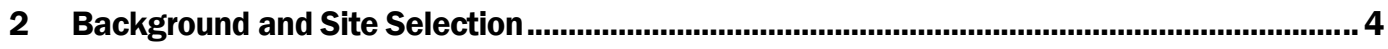

Status of the Red-cockaded Woodpecker and Its Recovery ............................................. 4

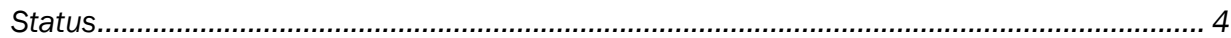

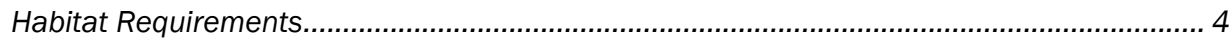

RCW Recovery Plan Guidelines for Habitat Management …........................................... 5

Habitat Management Guidelines for Gopher Tortoises..................................................... 6

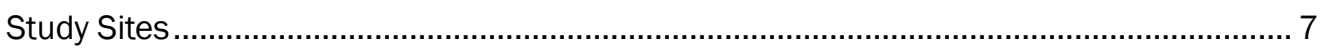

Tillman Sand Ridge Heritage Preserve (growing-season burn) .............................................. 8

Public Service Authority (no overall management) ............................................................ 10

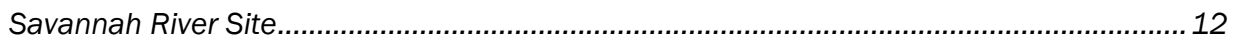

3 Methods................................................................................................................................14

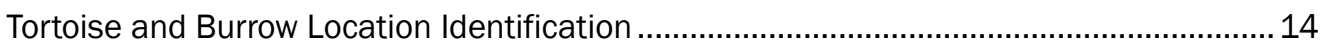

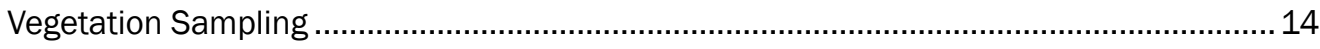

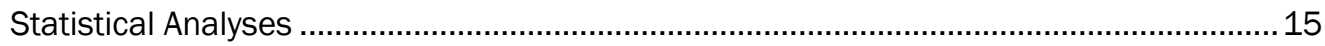

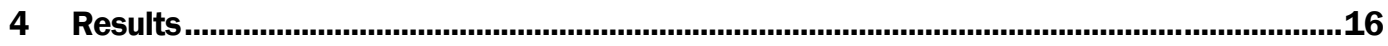

Comparison of Available Habitat Among Sites ............................................................ 16

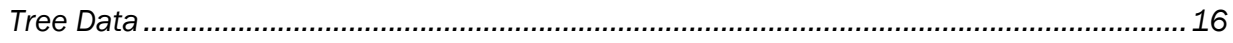

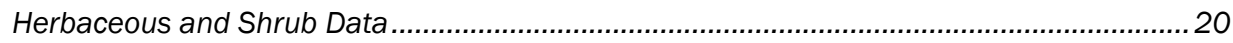

Comparison of Available Habitat to Tortoise-selected Habitat ...........................................23

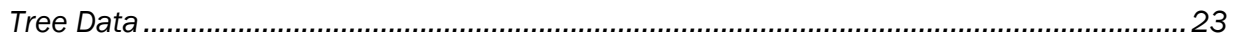

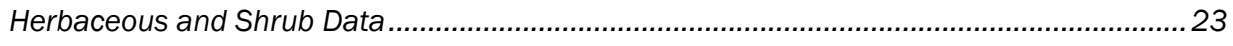

Comparison of Tortoise-selected Habitat Among Study Sites...........................................26

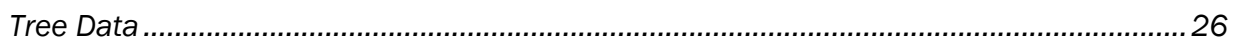

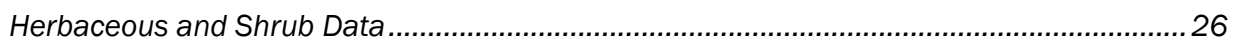

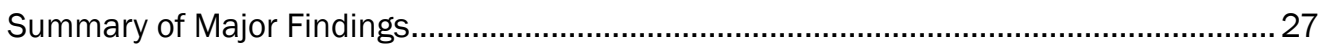

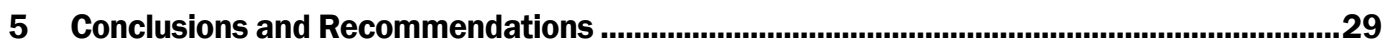

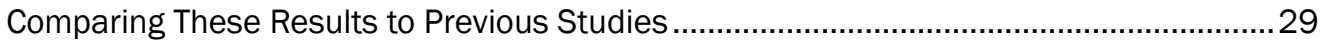

Determining Management Compatibility between Gopher Tortoise and RCW ...................30

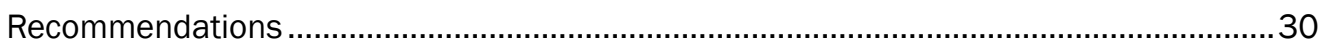

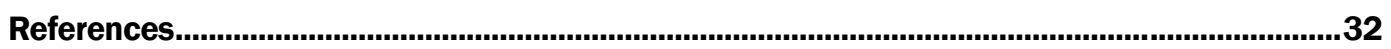

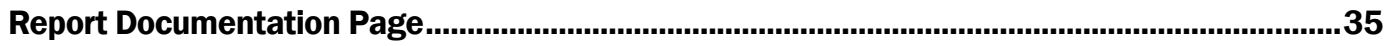




\section{Figures and Tables}

\section{Figures}

Figure 1. Location of four study sites in relation to distribution of the species (shaded). .................. 8

Figure 2. Tillman Sand Ridge (TSR) Heritage Preserve. .................................................................... 9

Figure 3. Public Service Authority (PSA) property illustrating the maintained grassy strips, dense hardwood understory, and lack of large pine trees............................................................ 10

Figure 4. Fort Gordon young pine (top left) and mature pine (top right) forests. .............................. 12

Figure 5. Gopher tortoise study site on the Savannah River Site (SRS). ........................................ 13

Figure 6. Percent canopy cover at random plots and burrows within each management prescription. 16

Figure 7. Tree density at random plots and burrows within each management prescription...........18

Figure 8. Total basal area $\left(\mathrm{m}^{2} / \mathrm{ha}\right)$ at random plots and burrows within each management prescription.

Figure 9. Pine basal area $\left(\mathrm{m}^{2} / \mathrm{ha}\right)$ at random plots and burrows within each management prescription.

Figure 10. Oak basal area ( $\left.\mathrm{m}^{2} / \mathrm{ha}\right)$ at random plots and burrows within each management prescription.

Figure 11. Percent shrub cover at random plots and burrows within each management prescription.

Figure 12. Percent wiregrass cover at random plots and burrows within each management prescription.

Figure 13. Percent cover of other grasses at random plots and burrows within each management prescription.

Figure 14. Percent cover of legumes at random plots and burrows within each management prescription.

Figure 15. Percent cover of other forbs at random plots and burrows within each management prescription.

Figure 16. Percent total herbaceous cover at random plots and burrows within each management prescription.

Figure 17. Number of burrows used during the 2 yr study period (2003-2004) by males and females under different forest management prescriptions.

\section{Tables}

Table 1. Designation of study sites and their background status.

Table 2. Summary of tree data at random locations in each management prescription

Table 3. Results of comparison of mean cover values for tree and herbaceous vegetation data at burrows relative to random plots under each management prescription.

Table 4. Summary of tree data at burrows under each management prescription. 


\section{Preface}

The research documented in this report was performed during the period 2003 through 2004 as part of Work Unit CNN-T063, Effects on Forestry on Gopher Tortoise, part of the thrust "Training Lands ManagementCharacterization, Analysis, and Mitigation," under program element A896, "Base Facilities Environmental Quality." The Technical Monitor was Scott Belfit.

This research was conducted under the guidance of Dr. Harold Balbach, Principal Investigator, U.S. Army Engineer Research and Development Center, Construction Engineering Research Laboratory (ERDC/ CERL), in support of the Army Threatened and Endangered Species Research Program. Ms. Tracey Tuberville was the Savannah River Ecology Laboratory Principal Investigator. Funding for the South Carolina Department of Natural Resources portion of the project was provided through the State Wildlife Grants Program. Additional funding was provided by the U.S. Forest Service-Savannah River, and report preparation was aided by the Environmental Remediation Sciences Division of the Office of Biological and Environmental Research, U.S. Department of Energy, through Financial Assistance Award No. DE-FC0996-SR18546 to the University of Georgia Research Foundation.

We are indebted to the following people who assisted in the field: J ason Norman, Brian Metts, Peri Mason, Wade Kalinowski, and Shaun Forkner. Kathryn Madden and Beverly Collins provided valuable advice on vegetation sampling and analysis. Leslie Zorn and Deno Karapatakis provided GIS and GPS support. We thank Ken Boyd for coordinating site access and assisting with logistics at Fort Gordon. The USFS-Savannah River, especially PeteJ ohnston, provided valuable logistical help and site coordination. Peggy Burkman and Margaret Wead assisted with data entry.

At the time this work was performed, Steve Hodapp was the TES Program Manager, Alan Anderson was Chief, CEERD-CN-N, and Dr. J ohn T. Bandy was Chief, CEERD-CN. The associated Technical Director was Dr. William D. Severinghaus, CEERD-CV-T. The Director of CERL was Dr. Ilker Adiguzel.

Colonel Richard B. J enkins was Commander and Executive Director of ERDC. Dr. J ames R. Houston was Director. 


\section{Introduction}

\section{Background}

The gopher tortoise (Gopherus polyphemus) occurs in the southeastern Coastal Plain and is the only tortoise species found east of the Mississippi River. It is associated with deep sandy soils and a wide variety of xeric habitats. Its historical habitat was the longleaf pine (Pinus palustris) forest, of which only about 2 percent remains (Noss et al. 1995). Due primarily to habitat loss, the species is considered declining throughout its range (Auffenberg and Franz 1982, Smith et al. in press). Although gopher tortoises are currently listed only in the western portion of their range (i.e., western Alabama, Mississippi, Louisiana; U. S. Fish and Wildlife Service [USFWS] 1987), many biologists familiar with the species believe that federal protection for the tortoise throughout its range is warranted. The USFWS has already been petitioned to list the Florida populations (Gopher Tortoise Petition J anuary 2006).

Most of the remaining viable populations occur on private lands or military installations (Hermann et al. 2002, Smith et al. in press). If the gopher tortoise were to be federally listed, conflicts between training missions and stewardship missions could develop. Gopher tortoises frequently occur sympatrically with the federally listed red-cockaded woodpecker (RCW; Picoides borealis), but it is not known what effects federally mandated management for RCWs might have on gopher tortoises. To the extent that the military - and other major landowners with large tortoise populations - can implement habitat management strategies that are compatible for both species, thereby preventing the need to list the gopher tortoise, both military training missions and species conservation goals can be achieved simultaneously.

This project was initiated to determine the effects of habitat management for RCWs on space use by gopher tortoises by monitoring movements of individual tortoises at sites with a wide range of habitat management prescriptions. Specifically, we examined habitat selection, home range size, burrow use, and site fidelity of gopher tortoises under specific management scenarios to evaluate whether habitat management guidelines for RCWs recommended in the RCW recovery plan (USFWS 2003), as cur- 
rently implemented on military installations, are complementary with management of gopher tortoises.

\section{Objective}

The study reported here had several objectives, but we will be concerned with only two of them. Although many biologists have observed that gopher tortoises prefer to make their burrows in the more open portions of their habitat, the characteristics of this "openness" have never been well quantified in terms of canopy cover and other vegetation characteristics. The first objective was to determine these factors for self-selected burrow sites within four habitats that illustrated a broad range of site characteristics.

Management prescriptions for the red-cockaded woodpecker have recently been reevaluated (USFWS 2003) and the degree of canopy cover and stem density now recommended for RCW management has been much decreased compared to previous recommendations. This raises the question among land managers who manage primarily for the RCW, and only secondarily for the tortoise, of whether the RCW management guidelines are suboptimal, acceptable, or excellent for the tortoises that may be living among the pine trees. The results of the forest cover measurements will be interpreted in terms of their relationships to RCW management prescriptions.

\section{Scope}

The four study sites were located at the northeastern limit of the species' range in the Upper and Lower Coastal Plains of South Carolina and Georgia, an area in which the ecology of the species is relatively unknown. Collectively, these four sites provide a broad range of forestry management prescriptions. The level of detail presented in this report on the previous management and land use histories varies across study sites and reflects the information currently available for these sites.

\section{Approach}

The immediate focus of the studies reported here was on the tortoise populations at four locations in northeastern Georgia and adjacent southeastern South Carolina. The study sites were Fort Gordon, GA, the Department of Energy Savannah River Site, The South Carolina Department 
of Natural Resources Tillman Sand Ridge state wildlife preserve, and a private hunting preserve in County SC. Fifty-nine different tortoises were identified, tagged, and tracked during two seasons to determine their habitat usage patterns. Vegetation data were collected at both randomly selected plots and in the immediate vicinity of selected tortoise burrows at all four study sites. The results of the vegetation sampling, especially the forest canopy cover data, were compared to relevant recommended redcockaded woodpecker management guidelines to evaluate similarities and differences.

\section{Mode of Technology Transfer}

The information included in this report is one portion of the materials prepared by the Engineer Research and Development Center (ERDC) to assist installation natural resources and TES program managers. The gopher tortoise is the first species in a planned series of studies that treat management of Species at Risk as they relate to military installation management plans. The primary means of communicating the tortoise behavior information will be through publication in the scientific literature, as well as through the availability of this report. The specific data presented are intended to be used in the preparation of biological opinions related to planned Army actions where the gopher tortoise is present. The data also will be used for preparation of management plans, integrated natural resources management plans (INRMPs), and in the preparation of ecological risk assessments involving training and other land-disturbing activities where the tortoise is present. This report will be made accessible through the World Wide Web (WWW) at URL http:// www.cecer.army.mil. 


\section{Background and Site Selection}

\section{Status of the Red-cockaded Woodpecker and Its Recovery}

\section{Status}

The red-cockaded woodpecker is a federally listed endangered species endemic to open, mature, and old growth pine ecosystems in the southeastern United States. According to the "Executive Summary of the 2003 RCW Recovery Plan," currently there are an estimated 14,068 red-cockaded woodpeckers living in 5,627 known active clusters across 11 states. This is less than 3 percent of estimated abundance at the time of European settlement. Red-cockaded woodpeckers were given federal protection with the passage of the Endangered Species Act in 1973. Despite this protection, all monitored populations (with one exception) declined in size throughout the 1970's and into the 1980's. In the 1990's, in response to intensive management based on a new understanding of population dynamics and new management tools, most populations were stabilized and many showed increases. Other populations remain in decline, and most have small population sizes. The major challenge now is to bring about the widespread increases in population sizes necessary for recovery (USFWS 2003).

\section{Habitat Requirements}

Red-cockaded woodpeckers require open pine woodlands and savannahs with large old pines for nesting and roosting habitat (clusters). Cavity trees must be in open stands with little or no hardwood midstory and few or no overstory hardwoods. Hardwood encroachment resulting from fire suppression is a well-known cause of cluster abandonment. Red-cockaded woodpeckers also require abundant foraging habitat. Suitable foraging habitat consists of mature pines with an open canopy, low densities of small pines, little or no hardwood or pine midstory, few or no overstory hardwoods, and abundant native bunchgrass and forb groundcovers (USFWS 2003).

Open stands of pines with a minimum age of 80 to 120 years, depending on the site, provide suitable nesting habitat. Longleaf pines (Pinus palustris) are most commonly used, but numerous other species of southern pine are also acceptable. Nest cavities, and successful colonies, have been 
found in loblolly (P. taeda), shortleaf (P. echinata), slash (P. elliottii), and Virginia (P. virginiana) pines, and occasionally other species, with and without association with longleaf. Foraging habitat is provided in pine and pine hardwood stands 30 years old or older with foraging preference for pine trees 10 inches $(25.4 \mathrm{~cm})$ or larger in diameter. In good, well-stocked, pine habitat, sufficient foraging substrate can be provided on 80 to 125 acres (32.4 to 50.6 hectares). The main criterion appears to be that the cavity trees must be of adequate size (at least $30 \mathrm{~cm}$ in diameter, and preferably larger), and spaced such that the canopy is not continuous. Mixed pine species are tolerated well if these criteria are met, and a mixture of scattered hardwoods often is seen to be accepted so long as they are not allowed to form a continuous, shaded canopy, either upper or mid-story. Dense stands (stands that are primarily hardwoods, or that have a dense hardwood understory) are avoided (USFWS 2003).

\section{RCW Recovery Plan Guidelines for Habitat Management}

The habitat described above is not typical of that found at the present time across most of the former RCW range, significant portions of which are, or were, shared with the gopher tortoise. The 2003 recovery plan for the RCW (USFWS 2003) gives the above description of high-quality RCW foraging habitat, as well as specific management targets for maintaining or restoring high quality foraging habitat. In general, the "... key components include: (1) native, site-appropriate canopy pine species, (2) old-growth pines, (3) lower density of canopy pines than in most second and thirdgrowth forests, and (4) healthy forb and bunchgrass groundcovers." The overall structure of the habitat should consist of large, widely spaced pines (preferably native longleaf) with few smaller-sized pine trees, few canopy hardwoods, an absent or very low mid-story shrub component, and abundant native ground cover vegetation. Group size, reproductive success, and stand selection are positively correlated with these variables (USFWS 2003, and references cited therein).

Specific targets for managing for high quality RCW foraging habitat include:

- large pines ( $\geq 35 \mathrm{~cm}$ dbh and $\geq 60 \mathrm{yrs}$ age): $45+$ stems/ha,

- mid-sized pines (25.4-35 cm dbh): basal area (BA) $\leq 9.2 \mathrm{~m} 2 / \mathrm{ha}$,

- small pines ( $<25.4 \mathrm{~cm}$ dbh): $<50$ stems/ ha and BA is $<2.3 \mathrm{~m} 2 / \mathrm{ha}$,

- mid-sized + large pines (all pines $\geq 25.4 \mathrm{~cm} \mathrm{dbh}$ ): $\mathrm{BA} \geq 9.2 \mathrm{~m} 2 / \mathrm{ha}$, 
- canopy hardwoods: absent or $<10 \%$ of canopy in longleaf pine forest, $<30 \%$ of canopy in loblolly pine forests,

- hardwood midstory: absent or $<2.1 \mathrm{~m}$ in height,

- herbaceous groundcover: $\geq 40 \%$ cover.

One of the most important and effective management tools for restoring and maintaining the desired habitat structure is prescribed fire. The RCW recovery plan recommends early to mid-growing season fire every 1 to 5 years to maintain habitat (USFWS 2003). Sites needing intensive management (e.g., hardwood control) and restoration, should initially be burned every 1 to 3 years, with non-growing-season fires implemented as needed to reduce fuel loads. However, once the desired fuel-reduction has been achieved, prescribed fires should be switched to growing season fire.

Although a "...common anxiety is that prescribed burning during growing season may have detrimental effects on non-target species," the low incidence of documented direct mortality to other species (such as game species and neotropical migratory birds) is a minor concern relative to the benefits that they obtain from maintenance of the forest structure (USFWS 2003). Early growing-season fires, compared to late growing-season or non-growing-season fires, also more closely mimic historical natural processes, are less likely to cause mortality of overstory pines, promote native ground cover, and more effectively control midstory shrubs. However, at sites needing intensive management or where fire is difficult to implement, mechanical removal or chemical control methods may need to be used-either alone or in combination with fire.

\section{Habitat Management Guidelines for Gopher Tortoises}

The recovery plan for the western population (Louisiana, Mississippi, and western Alabama) of gopher tortoises provides minimal guidance on how to manage their habitat. Beyond stating that an "abundance of herbaceous ground cover" and "a generally open canopy and sparse shrub cover" characterize good tortoise habitat (USFWS 1990), no specific management targets are provided. Although the need for more detailed habitat requirements of tortoises and specific management targets was noted more than a decade ago (Burke and Cox 1988, Germano and Bury 1994), few data are currently available. 
The following management targets have been suggested for gopher tortoises based on studies conducted since the publication of the 1990 recovery plan:

- canopy cover: $\leq 60 \%$ (Wilson et al. 1997); Berish (2001) recommends a mosaic of small treeless patches intermixed with forested areas with $\leq$ $50-70 \%$ cover and canopy cover of $\leq 30-40 \%$ for most of the site,

- pine BA: $30 \mathrm{~m} 2 /$ ha (Aresco and Guyer 1999),

- prescribed fire: growing season burn every 2-5yrs, with an initial nongrowing season fuel-reduction fire and more frequent growing season burns (every 1-3 yrs) for sites in need of intensive management. Where growing-season fire is not possible, more frequent non-growing season fires (every 1-2 yrs) should be implemented (Aresco and Guyer 1999, Berish 2001, Cox et al. 1987, Wilson et al. 1997).

Other variables, based on one or more studies of movement patterns and burrow use, that appeared to influence space use by gopher tortoises in at least some cases, include:

- total BA, hardwood BA, tree density (Aresco and Guyer 1999),

- total herbaceous cover (Auffenberg and Iverson 1979, Cox et al. 1987),

- percent cover of wiregrass, other grasses, and legumes (Cox et al. 1987, Garner and Landers 1981)

- shrub cover (Cox et al. 1987).

\section{Study Sites}

The four study sites for this research were located at the northeastern limit of the species' range in the Upper and Lower Coastal Plains of South Carolina and Georgia (Figure 1), an area in which the ecology of the species is relatively unknown. Collectively, these four sites provide a broad range of forestry management prescriptions (Table 1). The level of detail presented in this report on the previous management and land use histories varies across study sites and reflects the information currently available for these sites. 


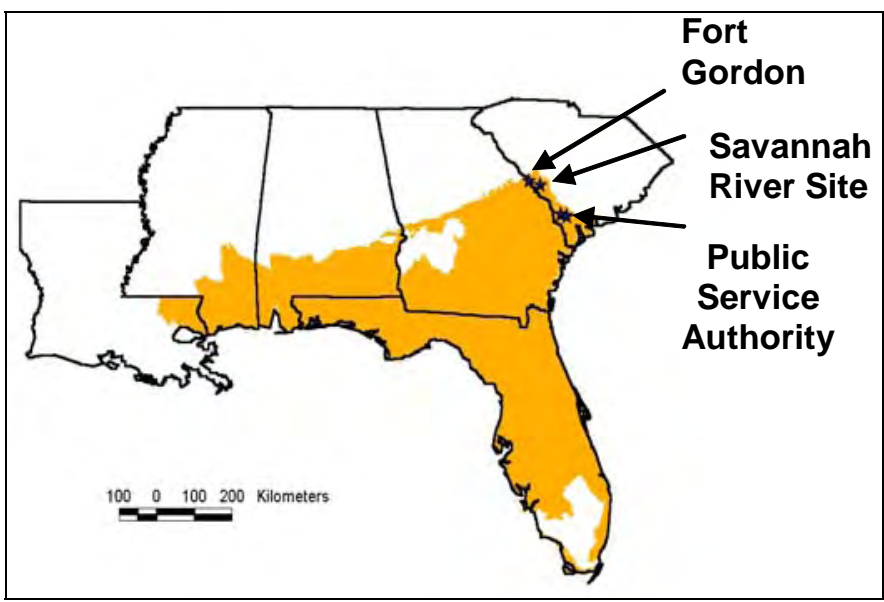

Figure 1. Location of four study sites in relation to distribution of the species (shaded).

Table 1. Designation of study sites and their background status.

\begin{tabular}{|l|l|l|l|}
\hline Study Site & $\begin{array}{l}\text { Land } \\
\text { ownership }\end{array}$ & Land use & Management prescription \\
\hline Fort Gordon (FTG) & U.S. DOD & Military training & $\begin{array}{l}\text { Burn' }+ \text { mechanical re- } \\
\text { moval of hardwoods }\end{array}$ \\
\hline $\begin{array}{l}\text { Tillman Sand Ridge } \\
\text { Heritage Preserve } \\
\text { (TSR) }\end{array}$ & SCDNR & Wildlife preserve & Growing season burn \\
\hline $\begin{array}{l}\text { Public Service Authority } \\
\text { (PSA) }\end{array}$ & Private & Hunting preserve & No management \\
\hline $\begin{array}{l}\text { Savannah River Site } \\
\text { (SRS) - translocated } \\
\text { population }\end{array}$ & U.S. DOE & Defense facility & Dormant season burn \\
\hline 1Both growing season and dormant season burns are conducted \\
\hline
\end{tabular}

\section{Tillman Sand Ridge Heritage Preserve (growing-season burn)}

Tillman Sand Ridge Heritage Preserve (TSR; Figure 2) is located in J asper County, in the extreme southeastern corner of South Carolina. The preserve is owned and managed by South Carolina Department of Natural Resources specifically for the purpose of managing the resident gopher tortoise population. Previous surveys for gopher tortoises were conducted in 1974-1975 (Auffenberg and Franz 1982), 1977-1979 (Wright 1982), and 1998 (Tuberville and Dorcas 2001) and indicate that the TSR population of gopher tortoise is the largest in the state. Although RCWs do not actually occur on the preserve, breeding populations are known from Webb Wildlife Center (also owned by SCDNR), which is within $10 \mathrm{~km}$ of TSR.

The preserve is approximately 360 ha in size, and includes lands along the Savannah River. Vegetation alliances are approximately 55 percent xeric 
sandhill, 28 percent bald cypress (Taxodium distichium)-tupelo gum (Nyssa spp.) swamp, and 17 percent mixed hardwoods (Dozier and Stowe 1999). The lower-lying lands, about half the area, are not tortoise habitat. The property had been owned by a commercial timber company and the planted slash pine (Pinus elliottii) stands were heavily thinned prior to its acquisition by SCDNR in 1984. Longleaf pine (P. palustris) has since regenerated on the site, both naturally and through planting of seedlings. The site has been burned approximately every 3 to 5 years for the past 12 years, primarily during the growing season (May - J uly). The groundcover is dominated by wiregrass (Aristida stricta) but also includes a diversity of other herbaceous species (Tuberville 1998). All soils are of the Buncombe Association (USDA 1980; per Coker and Murphy 1993).

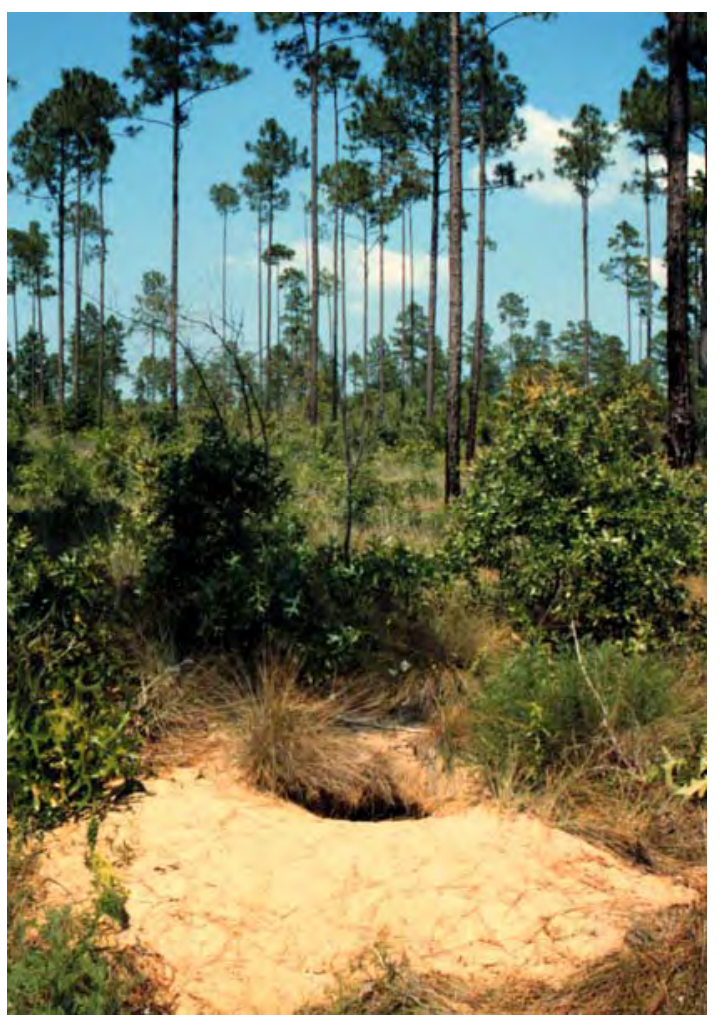

Figure 2. Tillman Sand Ridge (TSR) Heritage Preserve. 


\section{Public Service Authority (no overall management)}

The Public Service Authority property (PSA; Figure 3) was acquired by the state of South Carolina in 1985 as a potential utilities production site but is currently under lease to a private hunting club. This site supports few pine trees of sufficient size and age to provide cavity sites for RCWs, which are absent from the site. All merchantable timber was removed in the late 1980 's and the tract has not been burned in at least 20 years. The tract is approximately 400 ha, the majority of which is underlain by Buncombe fluvial sands, suitable for gopher tortoises. The PSA is approximately 3.5 $\mathrm{km}$ northwest of TSR (from center to center). The hunt club management includes several food plots planted for deer and narrow ( $<5 \mathrm{~m}$ wide) grassy strips maintained for quail.

Although tortoises are numerous at this site, they are primarily restricted to maintained open areas, roadsides, and adjacent forest edges. The only known survey work was initiated by SCDNR at the beginning of this study.

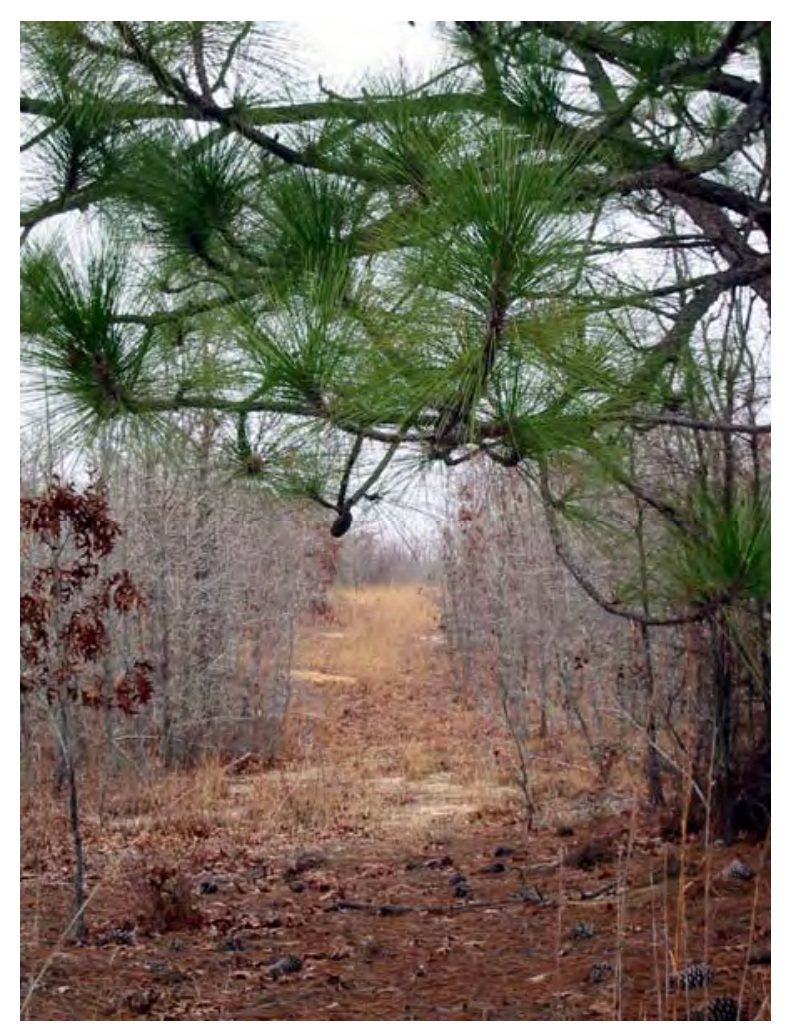

Figure 3. Public Service Authority (PSA) property illustrating the maintained grassy strips, dense hardwood understory, and lack of large pine trees. 


\section{Fort Gordon Military Reservation (growing season burn + mechanical removal)}

Fort Gordon (Figure 4) is located in portions of Richmond, McDuffie, and Columbia Counties, Georgia, approximately $13 \mathrm{~km}$ southwest of Augusta. The reservation is 22,400 ha in size. Fort Gordon was established in 1941 as Camp Gordon, became Fort Gordon in 1956, and since 1974 has been the home of the Army Signal School.

The reservation is divided into three Habitat Management Units (HMUs) for the federally endangered RCW. HMU-1, approximately 8000 ha, is the area of main RCW concentration (the center $1 / 3$ of Fort Gordon) and the management goal is to burn on a 3-year cycle. This study was restricted to Training Areas (TAs) 21 and 22 in HMU 1. The predominant soils in these areas are Lakeland and Troup, both sandy soils suitable for tortoises. Both growing-season and dormant-season fires are implemented, but Training Areas 21 and 22 are the only areas on the installation in which mechanical removal of mid-story vegetation (followed by growing-season fire) is routinely conducted, either with bulldozer or drum chopper. Forest stands within the training areas vary in age of stand and timing of management treatments. This study was conducted in both mature and young forests (Figure 4). The stands in which this study was conducted were most recently treated with growing-season fire in 2000 and/ or 2001, nongrowing-season fire in 2000 and/ or 2002, and mechanical removal in 2000, 2002 or 2003.

Disturbance due to military training in our study areas is low intensity and very localized, both spatially and temporally. Military training throughout the reservation is primarily restricted to foot traffic; off-road, tracked vehicles are not routinely used. The only regular mechanized training (using tracked vehicles) occurs about 2 to 3 times per year as part of the National Guard training exercises. Within TA21 and TA22, the military actively avoids training in these training areas because of potential conflicts with RCWs.

Previous survey work for tortoises was conducted by USFWS in 1991 to identify concentrations of tortoise burrows, although the burrows were neither enumerated nor spatially located in that survey. Since 2002, The Nature Conservancy-Fort Gordon staff has resurveyed sites of burrow concentrations that have been treated with fire since the last growing season. 

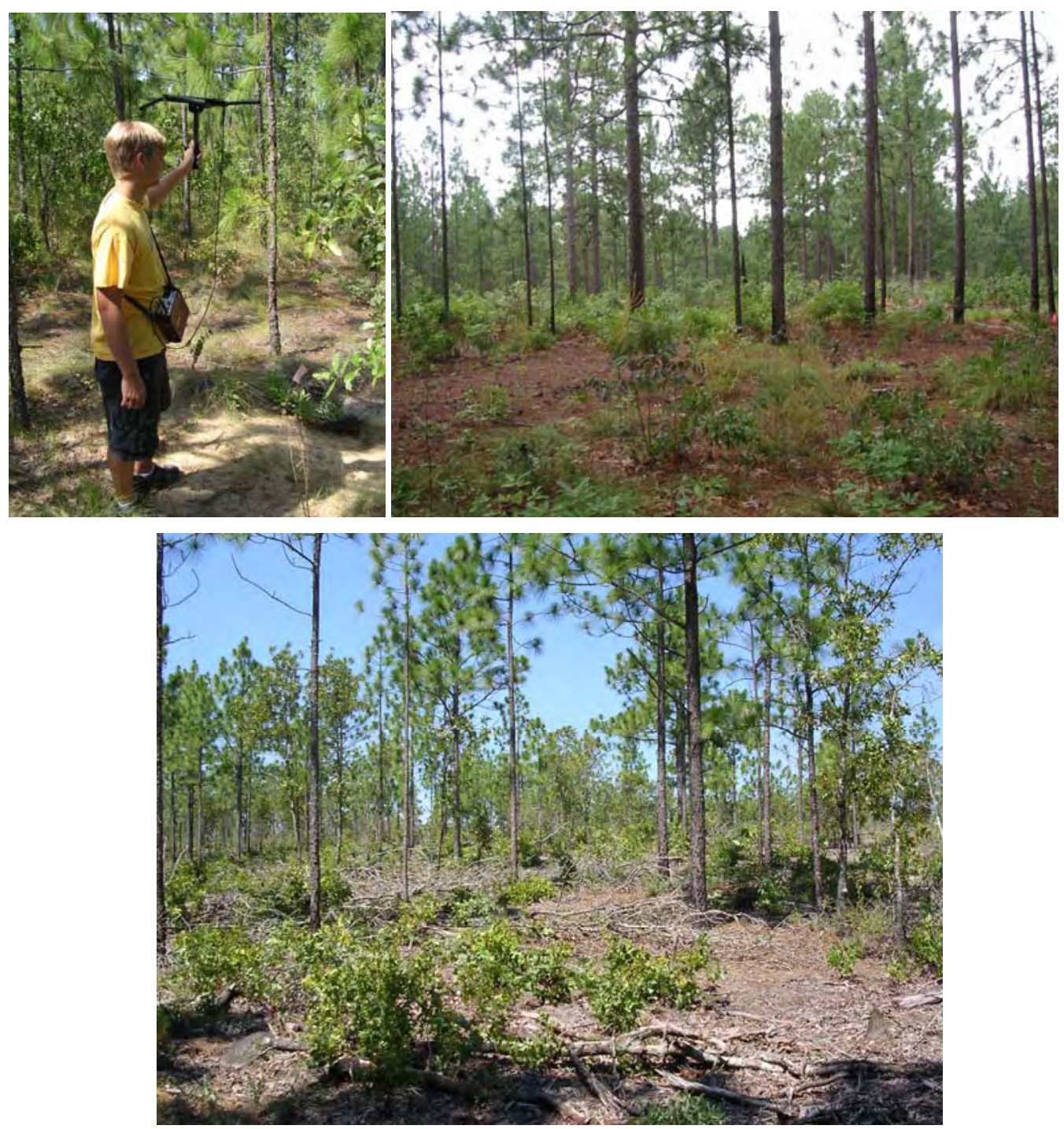

Figure 4. Fort Gordon young pine (top left) and mature pine (top right) forests. Also shown is another nearby stand (bottom center) in which mechanical removal of the hardwoods had recently been conducted.

\section{Savannah River Site}

The Savannah River Site (SRS; Figure 5) is a $750 \mathrm{sq} \mathrm{km} \mathrm{Federal} \mathrm{Reserve}$ located in Aiken County, South Carolina. The SRS is owned by the U.S. Department of Energy and managed by the U.S. Forest Service. The portion of the SRS where this study was conducted is in the northeast corner in a 882-ha timber management compartment. Thirty-seven percent of the stand occurs on Lakeland and 25 percent on Troup series soils, both with high sand content and suitable for tortoises. The forest type is primarily open-canopy longleaf pine (52 percent of compartment area), 
flanked by floodplain sweetgum (Liquidambar styraciflua) forests (13 percent), and interspersed with small patches of open-canopy loblolly pine (P. taeda), open-canopy mixed pines, upland hardwoods, and upland scrub forests ( 5 to 6 percent each). Longleaf pine has the highest dominance relative to other canopy species (86.4 percent) and the highest importance value (78.2), followed by loblolly pine (importance value 22.6 [K. Madden, unpublished data, SREL]). The estimated age of the timber stand is approximately 50 to 60 yrs (P. J ohnston, professional communication, USFS-Savannah River). The understory comprises a mixed-oak (Quercus spp.) shrub layer and a moderately dense and diverse herbaceous layer.

Most management is directed toward improving site conditions for the federally-endangered RCW (USFWS 1970). A portion of the site had been replanted in wiregrass (A. stricta), which had been eliminated on most of the SRS due to intensive agriculture prior to SRS's acquisition by DOE in the 1950s (White and Gaines 2000). The forest stand is burned approximately every 3 years, usually in the dormant season. It was most recently burned in spring 2001 and February 2003.

The SRS tortoise population was translocated to the SRS in fall 2001, and the process and its characteristics have been described elsewhere (Clark 2003, Tuberville et al. in press).

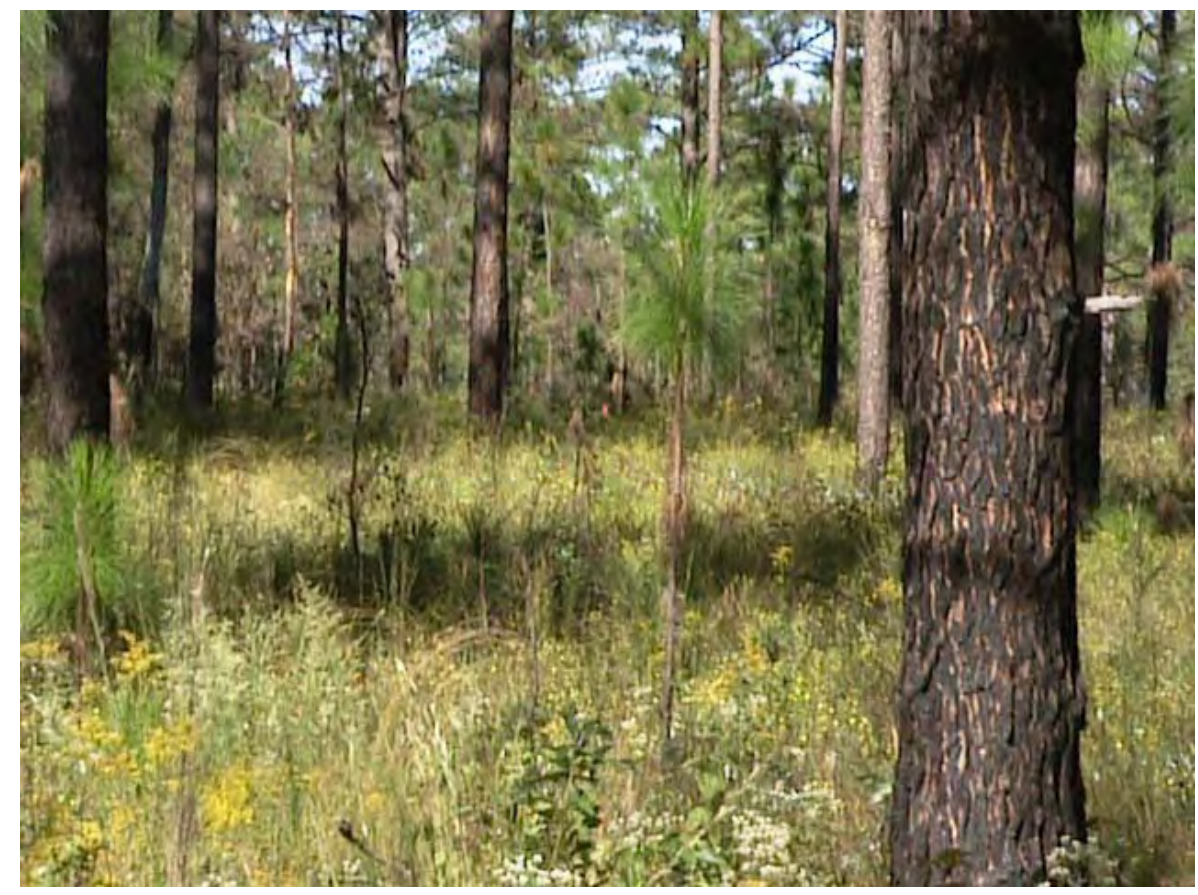

Figure 5. Gopher tortoise study site on the Savannah River Site (SRS). 


\section{Methods}

\section{Tortoise and Burrow Location Identification}

Tortoises were trapped using wire live traps placed at the entrance of tortoise burrows and covered with shade material. Traps were checked at least once every day. All tortoises were measured, sexed based on degree of plastral concavity (Iverson 1980; Landers et al. 1980), and permanently marked by drilling or filing notches in unique combinations of marginal scutes (Gibbons 1990). Only adult tortoises were used in this study. Each tortoise was fitted with a radio-transmitter (\#LF-2-2/3A-CTM-RS-T, LL Electronics, Mahomet, IL; ut $40 \mathrm{~g}$ with epoxy) mounted on the carapace.

Animals were located 2 to 3 times per week during the 2003 and 2004 active seasons. Burrows were marked and assigned a unique number. All tortoise and new burrow locations were recorded using GPS technology (Trimble Pro-XR, Sunnyvale, CA, with sub-meter accuracy). The movement tracking was conducted for a concurrent related study, and will not be discussed in any detail in this report.

\section{Vegetation Sampling}

Vegetation data were collected at both randomly-selected plots (hereafter, called "random plots") and in the immediate vicinity of selected tortoise burrows at all four study sites during September to October 2004. Trees were sampled using the point-quarter method. The following data were recorded for the nearest live tree $>2.5 \mathrm{~cm}$ diameter at breast height (dbh) in each quadrant: distance $(\mathrm{m}), \mathrm{dbh}$ in $\mathrm{cm}$, and tree type (pine, oak, other hardwood). In addition, percent canopy cover was estimated in each quadrant using a spherical crown densiometer and averaged over the four quadrants. Percent shrub cover was estimated in $2 \mathrm{~m} \times 2 \mathrm{~m}$ plots using the Braun-Blanquet cover score scale (absent, <5\%, 5-25\%, 25-50\%, 50-75\%, 75-100\%). Wiregrass, other grass, legumes, and other forbs were similarly quantified in $1 \mathrm{~m} \times 1 \mathrm{~m}$ herbaceous plots. Herbaceous plots were nested within shrub plots.

Potential locations of random plots were generated in ArcView 3.3 (Environmental Systems Research Institute, Inc., Redlands, CA, USA) using the RANDOM POINTS Extension. Random plots were a minimum of $50 \mathrm{~m}$ 
from each other and at least $10 \mathrm{~m}$ from a road or tortoise burrow. The target sampling intensity was 1 random plot per 1 to 2 ha of study area (i.e., the forest stand or stands which tortoises were known to use, as evidenced by the radio-tracking data). Burrows were selected from the list of burrows known to be used on at least 3 occasions by the animals radio-tracked during this study, and thus were considered "regularly used." Burrow plots were placed $1 \mathrm{~m}$ behind the burrow entrance to minimize potential impacts (e.g., soil disturbance, feeding) that tortoises might have on the vegetation surrounding their burrows (Boglioli et al. 2000). On the SRS, burrow plots included both tortoise-created burrows and starter burrows provided to tortoises at the time of their initial release at the translocation site. All SRS starter burrows that were sampled were verified to have been used by radio-tracked animals during the study period.

\section{Statistical Analyses}

Vegetation data were analyzed by comparing mean ranks among sites using Kruskal-Wallis and by comparing mean ranks between random plots and burrows using the Wilcoxon rank sum test. Prior to analyses, cover class scores were converted to percentages using the midpoint of the corresponding cover class. Alpha was set at 0.05 for all statistical procedures. 


\section{Results}

\section{Comparison of Available Habitat Among Sites}

\section{Tree Data}

The following habitat measures were significantly different among random plots from the four study sites: percent canopy cover, total BA, pine BA, oak BA, percent of total BA comprised of pine, and proportion of total BA comprised of oak ( $\mathrm{p}<0.0001$ for all comparisons). Percent canopy cover under growing season burn (hereafter, GS-burn; i.e., TSR) was significantly lower (38.4 percent) than all other management prescriptions, which had canopy cover values of approximately 55 percent (Figure 6). The GS-burn also had the lowest total BA and second lowest stem density. The canopy consisted of a few moderate-sized pine trees and many small oaks in the understory (as indicated by the low total BA but high relative percent BA represented by pine, and the moderate oak BA but high relative BA for oak; Table 2).

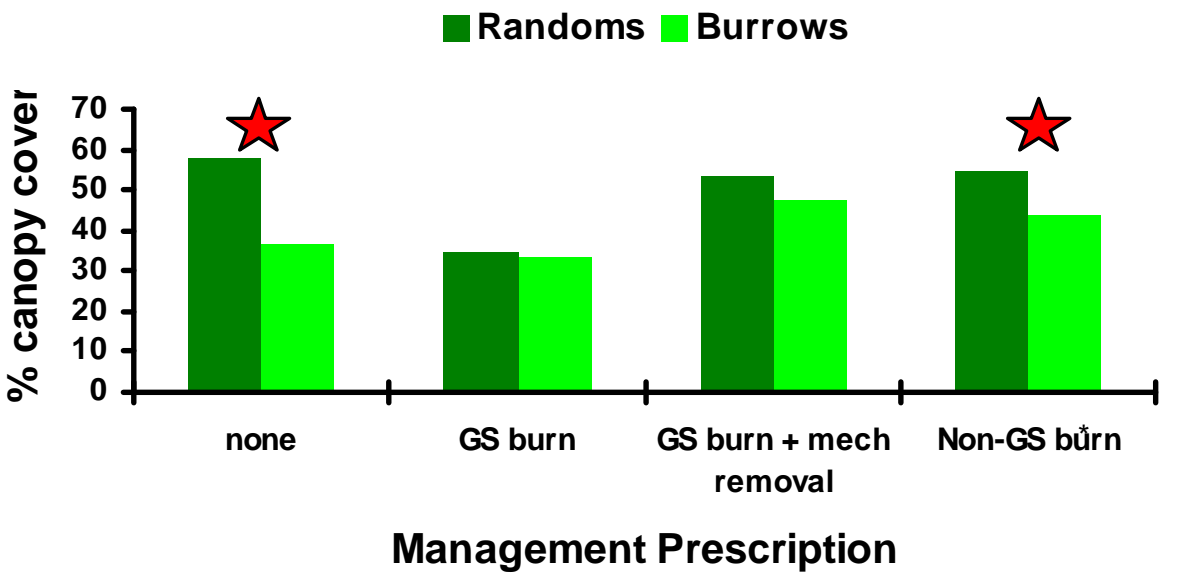

Figure 6. Percent canopy cover at random plots and burrows within each management prescription.

Significant comparisons between random plots and burrow locations are noted with a star. 
Table 2. Summary of tree data at random locations in each management prescription.

These areas represent "available habitat." Basal area (BA) is reported in $\mathrm{m}^{2} /$ ha and density (D) as stems/ha. Importance values (I.V.) and relativized values of BA and D are also reported. In addition to overall means, separate means for young and mature pine stands are provided for the GS burn + mechanical prescription (i.e., Fort Gordon).

\begin{tabular}{|c|c|c|c|c|c|c|c|c|c|c|c|c|c|c|c|c|}
\hline \multirow[b]{2}{*}{$\begin{array}{l}\text { Management } \\
\text { prescription }\end{array}$} & \multirow[b]{2}{*}{$n$} & \multicolumn{3}{|l|}{ Total } & \multicolumn{4}{|l|}{ Pine } & \multicolumn{4}{|l|}{ Oak } & \multicolumn{4}{|c|}{ Other hardwood spp. } \\
\hline & & $\begin{array}{l}\% \text { canopy } \\
\text { cover }\end{array}$ & BA & Density & BA & Rel BA & Rel D & I.V. & BA & Rel BA & Rel D & I.V. & BA & Rel BA & Rel D & I.V. \\
\hline none & 30 & 57.9 & 9.46 & 1603.5 & 4.69 & 49.65 & 9.17 & 24.87 & 4.00 & 42.27 & 85.00 & 66.98 & 0.74 & 7.84 & 5.00 & 6.91 \\
\hline GS burn & 30 & 34.8 & 8.27 & 368.2 & 6.98 & 84.39 & 31.67 & 52.79 & 1.29 & 15.61 & 68.33 & 47.21 & 0.00 & 0.00 & 0.00 & 0.00 \\
\hline $\begin{array}{l}\text { GS burn + } \\
\text { mechanical }\end{array}$ & 60 & 53.4 & 12.42 & 604.0 & 11.79 & 94.89 & 69.87 & 75.33 & 0.63 & 5.10 & 29.71 & 24.19 & $<0.01$ & 0.01 & 0.42 & 0.48 \\
\hline Young pine & 20 & 47.9 & 10.71 & 668.8 & 10.47 & 97.76 & 68.75 & 75.71 & 0.24 & 2.24 & 31.25 & 24.29 & 0.00 & 0.00 & 0.00 & 0.00 \\
\hline Mature pine & 40 & 56.2 & 13.23 & 574.9 & 12.42 & 93.88 & 70.44 & 75.29 & 0.81 & 6.10 & 28.93 & 23.99 & $<0.01$ & 0.02 & 0.63 & 0.73 \\
\hline Non-GS burn & 25 & 54.7 & 18.95 & 322.7 & 18.52 & 97.73 & 83.00 & 84.05 & 0.34 & 1.81 & 15.00 & 13.22 & 0.09 & 0.46 & 2.00 & 2.73 \\
\hline
\end{tabular}


Despite having a low basal area, the 'no management' site (PSA) had the highest tree density (Figure 7 and Figure 8 ). The 'no management' site had the lowest pine BA and the highest oak BA values, resulting in much higher importance values for oaks than pines (Table 2, Figure 9 and Figure 10). In contrast, the non-GS burn site (i.e., SRS) had the highest total BA and pine BA but lowest tree density. The non-GS burn site consists of large trees, which were almost exclusively pine.

Like the non-GS burn site, the 'GS-burn + mechanical' site (i.e., Fort Gordon) had moderate to high total BA and pine BA. Relative to the nonGS burn site, pine in the 'GS-burn + mechanical' site had a lower importance value due to the greater abundance of oak in the understory. However, none of canopy measures were significantly different between the two sites. The younger pine stand had lower canopy cover, and slightly lower total BA, pine BA, and oak BA relative to the mature pine stands (Table 2), but these differences were not significant.

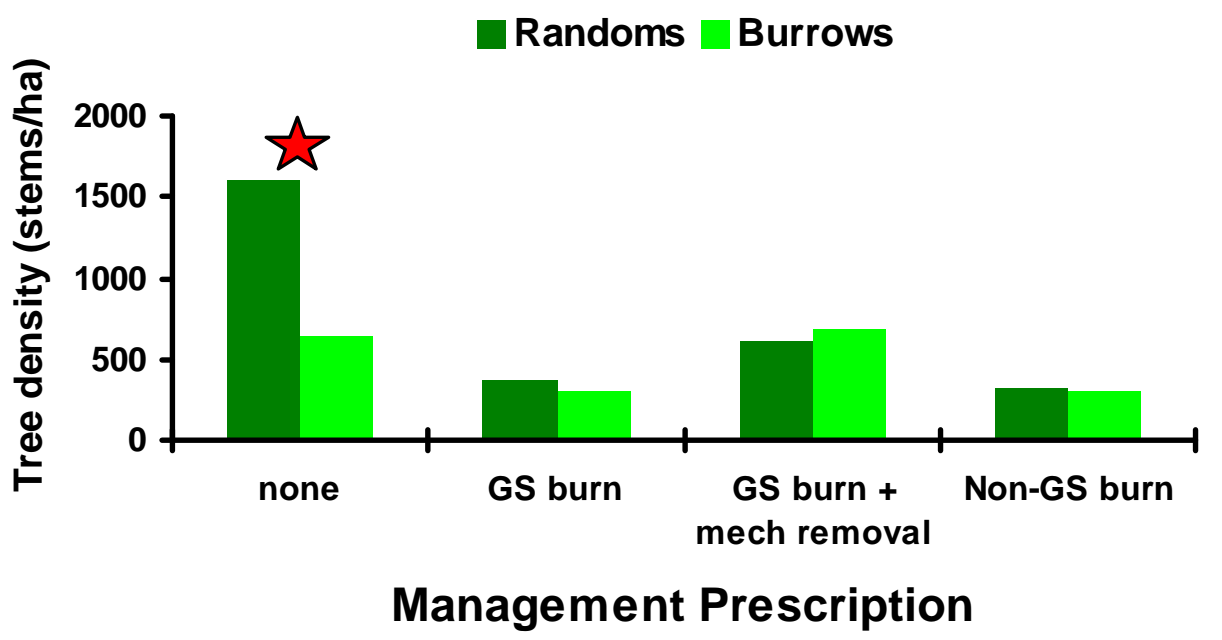

Figure 7. Tree density at random plots and burrows within each management prescription. Significant comparisons between random plots and burrow locations are noted with a star. 


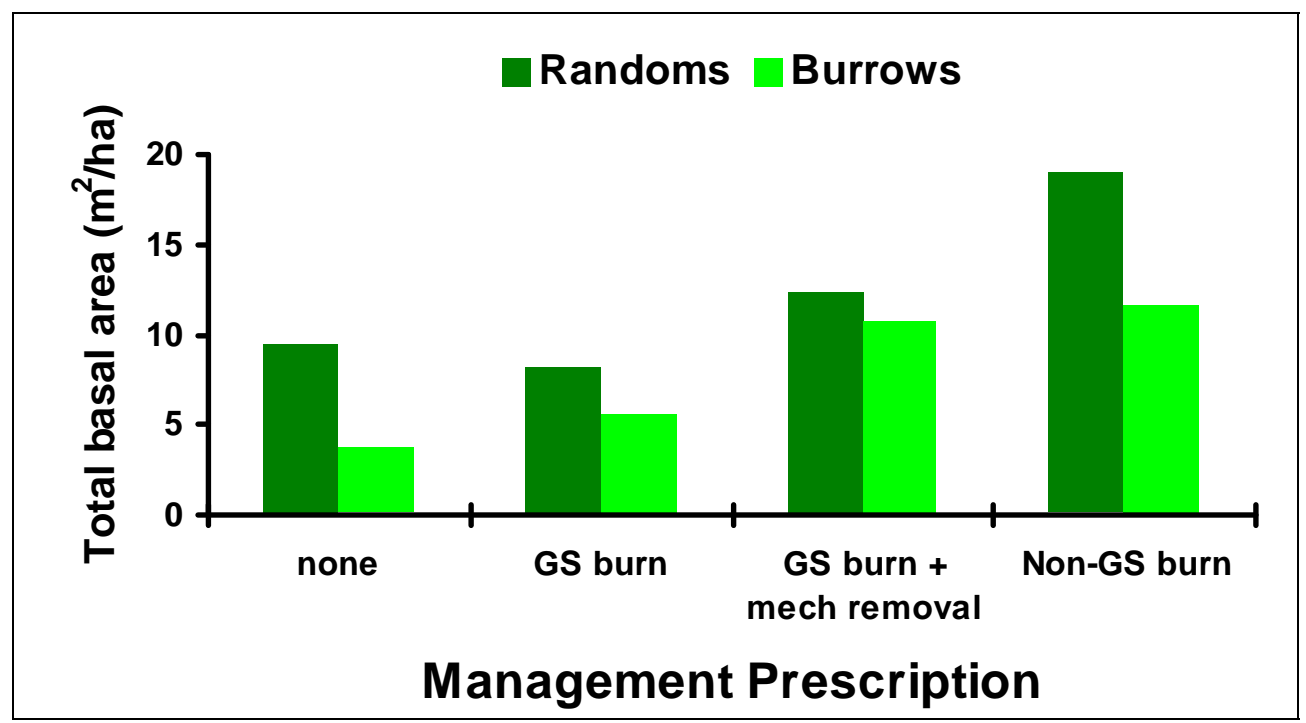

Figure 8. Total basal area $\left(\mathrm{m}^{2} / \mathrm{ha}\right)$ at random plots and burrows within each management prescription.

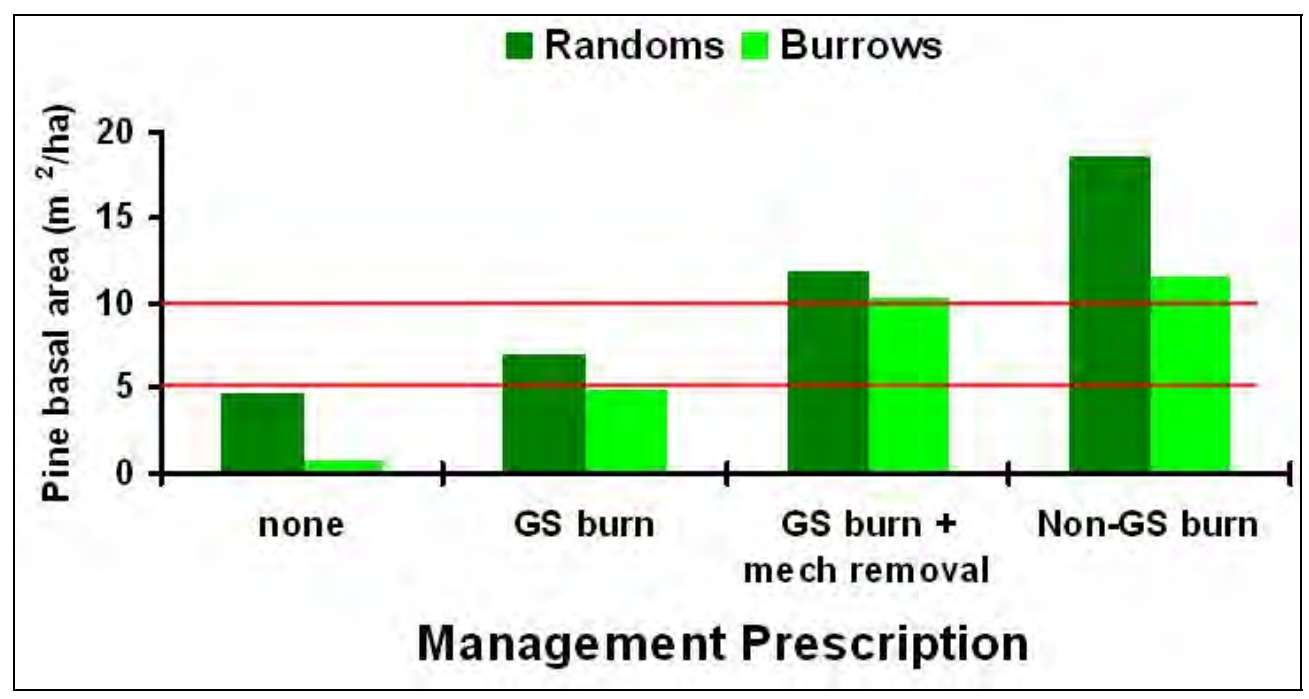

Figure 9. Pine basal area ( $\left.\mathrm{m}^{2} / \mathrm{ha}\right)$ at random plots and burrows within each management prescription.

The range of values recommended in the RCW recovery plan is indicated by the red lines. 


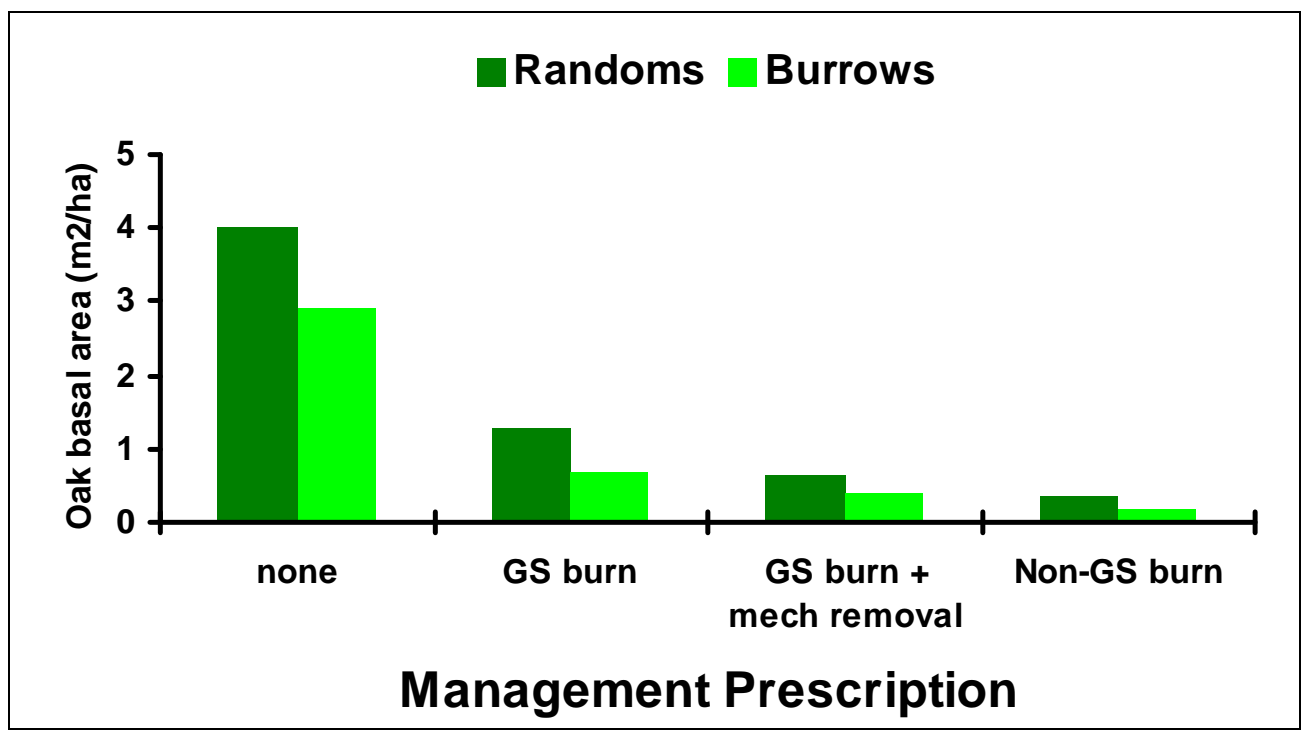

Figure 10. Oak basal area $\left(\mathrm{m}^{2} / \mathrm{ha}\right)$ at random plots and burrows within each management prescription.

\section{Herbaceous and Shrub Data}

Available habitat at random plots was similar among the 'GS-burn, 'GSburn + mechanical' and the 'non-GS burn sites with respect to the herbaceous components examined (Figure 11 through Figure 16), although the 'GS-burn + mechanical' and the 'no management' sites tended to have lower percent cover of shrubs and all herbaceous components. The GSburn site was distinctly different in its higher shrub, wiregrass, and legume cover.

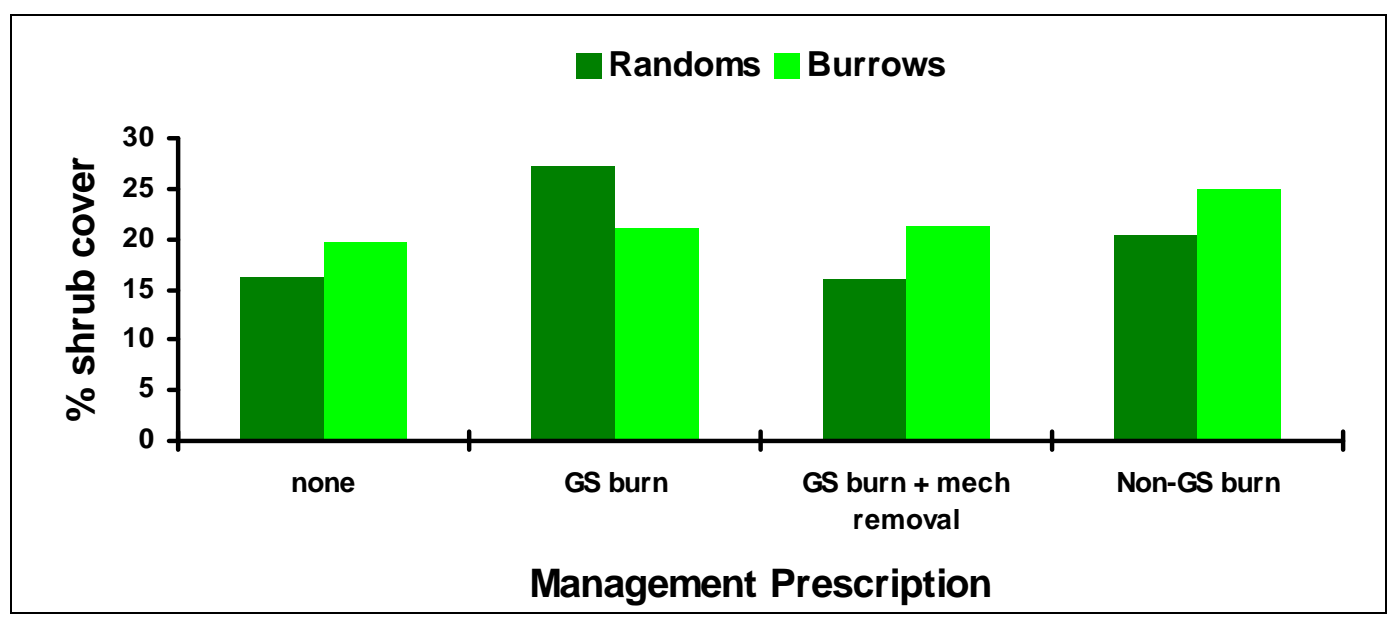

Figure 11. Percent shrub cover at random plots and burrows within each management prescription. 


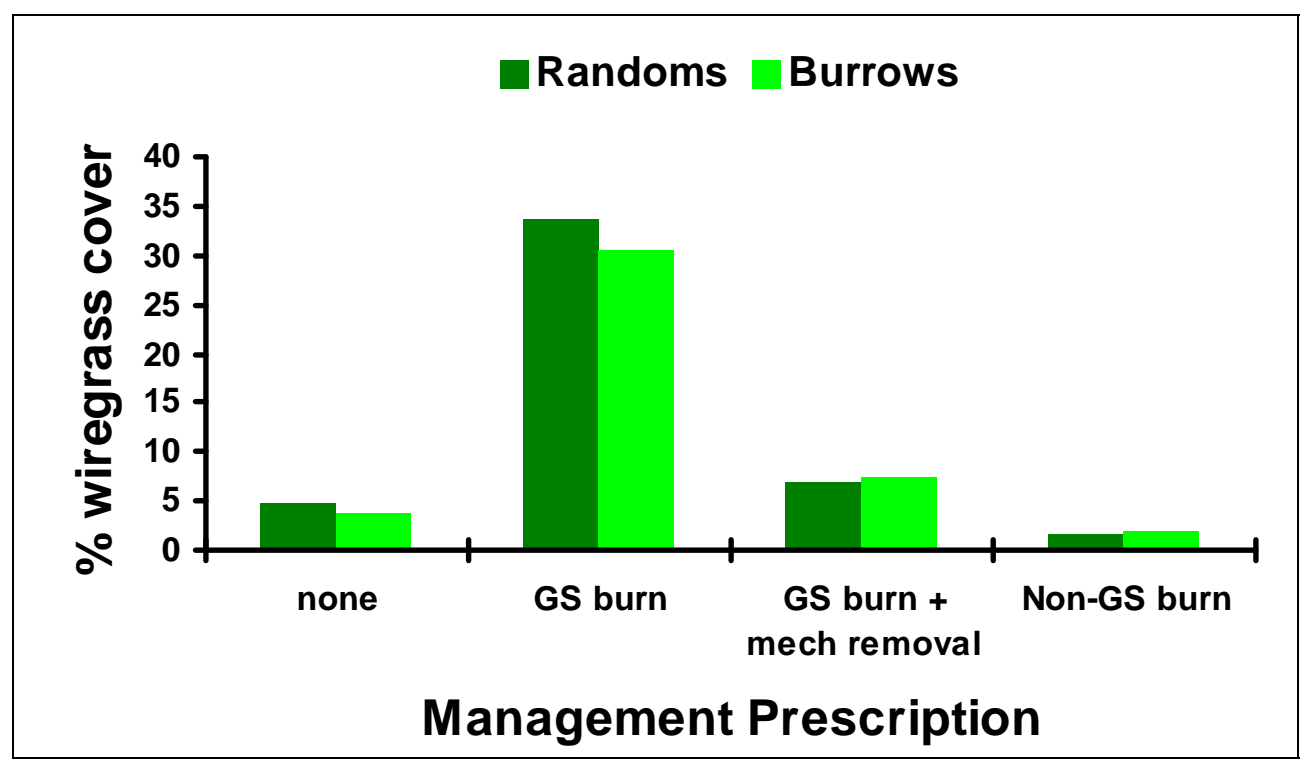

Figure 12. Percent wiregrass cover at random plots and burrows within each management prescription.

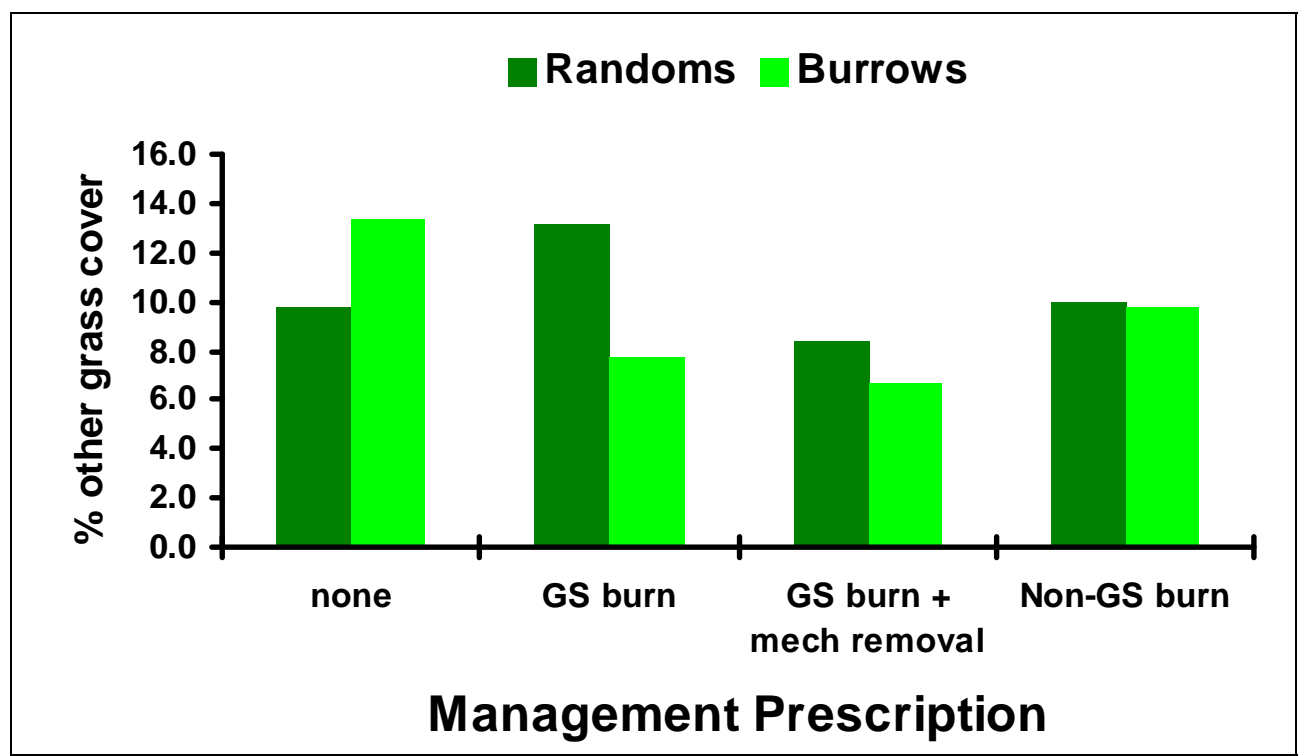

Figure 13. Percent cover of other grasses at random plots and burrows within each management prescription. 


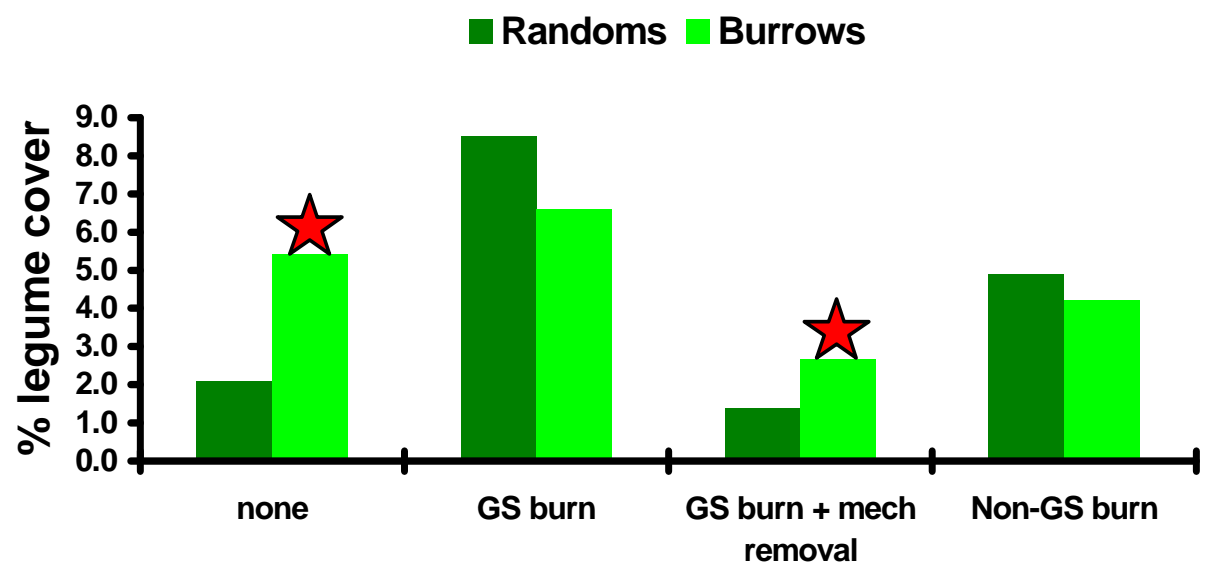

Management Prescription

Figure 14. Percent cover of legumes at random plots and burrows within each management prescription.

Significant comparisons between random plots and burrow locations are noted with a star.

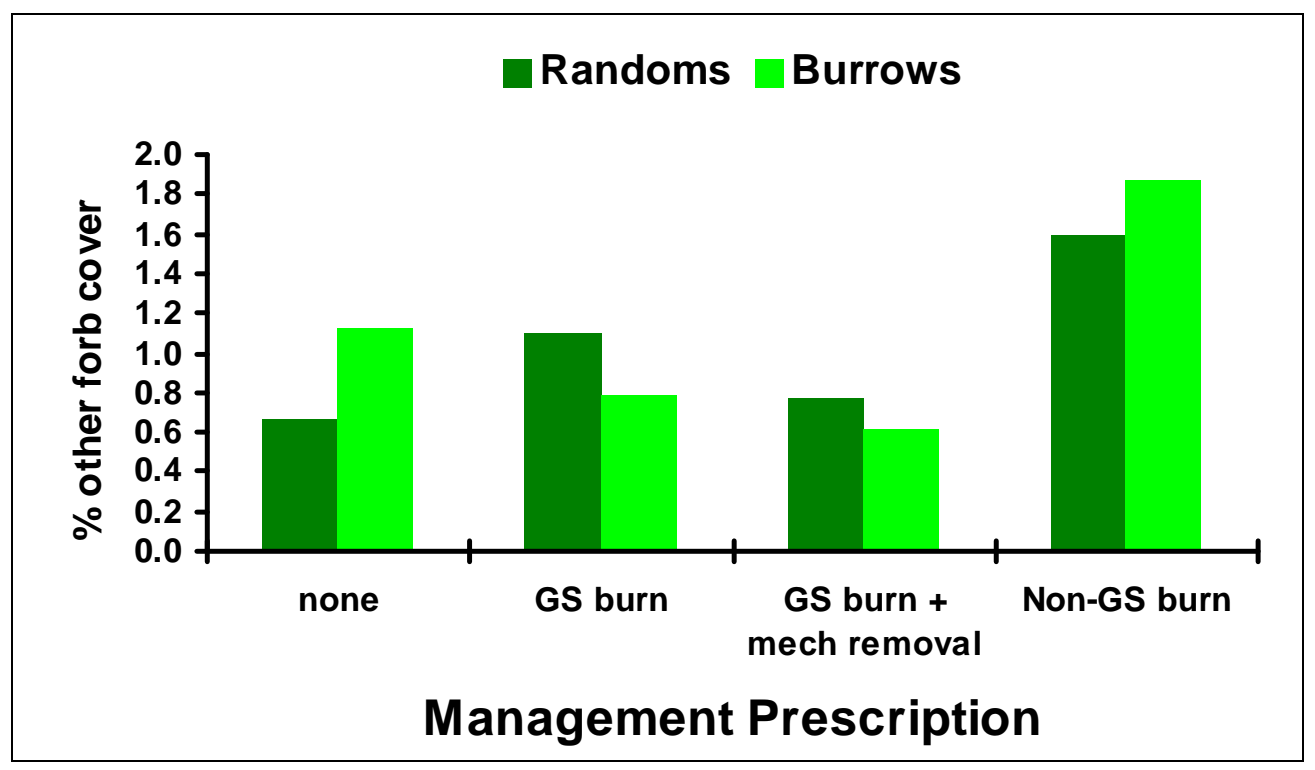

Figure 15. Percent cover of other forbs at random plots and burrows within each management prescription. 


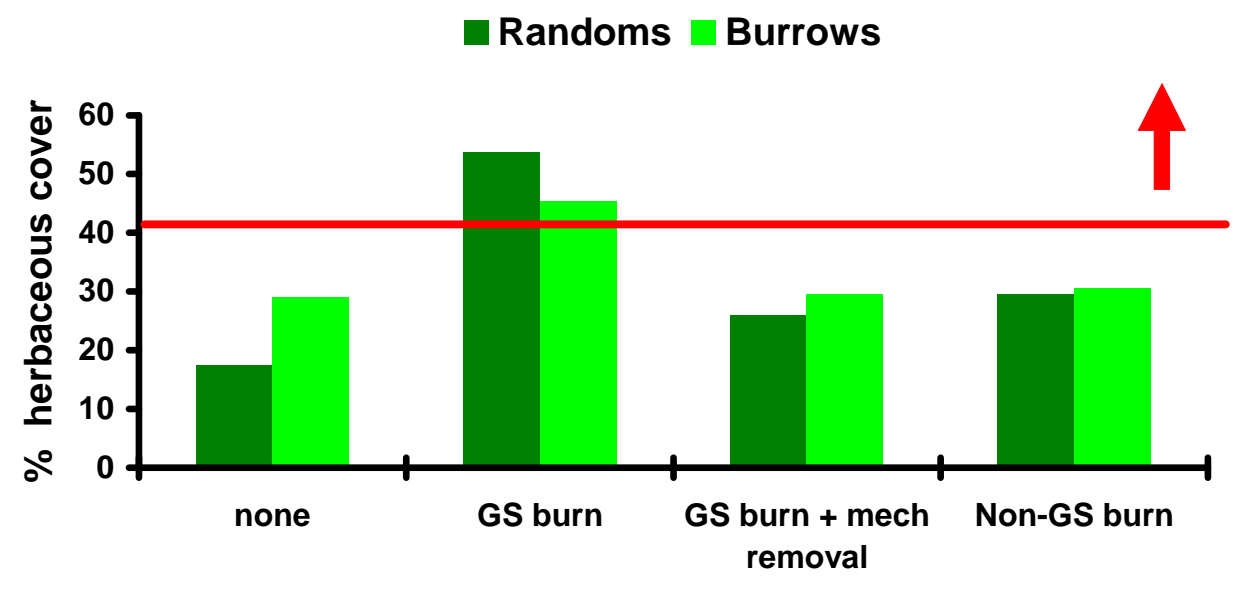

Management Prescription

Figure 16. Percent total herbaceous cover at random plots and burrows within each management prescription.

The values recommended in the RCW recovery plan are indicated by the red line and arrow.

\section{Comparison of Available Habitat to Tortoise-selected Habitat}

Tree Data

Canopy cover was significantly lower at tortoise-selected habitat (i.e., in the square meter immediately behind the tortoise burrows) than at random plots, except when canopy cover was extremely low throughout the study site (i.e., GS-burn site) or when availability of sites with lower canopy cover was limited (i.e., 'GS-burn + mechanical'; Figure 6, Table 3).

Likewise, total, pine, and oak BA were all lower at tortoise burrows than at random plots (Figure 8 through Figure 10). The only study site where habitat selection by tortoises was affected by tree density was the 'no management site', where tree density was approx. three times that of the other study sites (Figure 7).

\section{Herbaceous and Shrub Data}

With a few exceptions, herbaceous vegetation components were remarkably similar between random plots and burrows (Table 3). The most striking differences were the significantly higher percent cover of legumes at burrows relative to random plots at 'GS-burn + mechanical' and 'no management' sites-the sites with the lowest availability of legumes (Figure 14). In contrast, wiregrass (also generally presumed to be an important food item for gopher tortoises) abundance at burrows generally reflected wiregrass abundance in the available habitat at each of the study sites 
(Figure 12). Percent shrub cover was higher at burrows compared to random locations except under GS-burn, which had significantly higher shrub cover in available habitat compared to other sites. Tortoises in GS-burn prescription selected sites with lower mean cover than in the available habitat, resulting in similar percent shrub cover at burrows across all management prescriptions (Figure 11). Only the GS-burn management prescription produced sufficient total herbaceous cover to meet the criteria outlined in the RCW recovery plan (USFWS 2003; Figure 16).

Table 3. Results of comparison of mean cover values for tree and herbaceous vegetation data at burrows relative to random plots under each management prescription Wilcoxon rank sum test, alpha $=0.05$. Only $p$-values for significant (in bold) and nearly significant comparisons are reported; all other comparisons were not significant (NS).

\begin{tabular}{|l|l|l|l|l|}
\hline Habitat Measure & None & GS-burn & GS-burn + mech removal & Non-GS burn \\
\hline Tree and shrub data & \multicolumn{5}{l|}{} \\
\hline$\%$ canopy & 0.0022 & NS & NS & 0.002 \\
\hline Basal area & NS & NS & NS & NS \\
\hline Pine basal area & NS & NS & NS & NS \\
\hline$\%$ pine basal area & NS & NS & NS & 0.0252 \\
\hline Oak basal area & NS & 0.0704 & NS & 0.0765 \\
\hline$\%$ oak basal area & NS & NS & NS & 0.0583 \\
\hline Herbaceous cover data & & & & NS \\
\hline Shrub & NS & NS & NS & NS \\
\hline Wiregrass & NS & NS & NS & NS \\
\hline Other grass & NS & 0.043 & NS & NS \\
\hline Legumes & 0.0288 & NS & 0.0499 & NS \\
\hline Other forbs & NS & 0.0142 & NS & \\
\hline
\end{tabular}


Table 4. Summary of tree data at burrows under each management prescription.

These areas represent "tortoise-selected" habitat. Basal area (BA) is reported in $\mathrm{m} 2 /$ ha and density (D) as stems/ha. Importance values (I.V.) and

relativized values of BA and D are also reported. In addition to overall means, separate means for young and mature pine stands are provided for 'GS-burn

+ mechanical' (i.e., FTG) and for tortoise-created burrows (TB) and starter burrows (SB; provided to translocated tortoises) at 'non-GS burn' site (i.e., SRS).

\begin{tabular}{|c|c|c|c|c|c|c|c|c|c|c|c|c|c|c|c|c|}
\hline \multirow[b]{2}{*}{ Site } & \multirow[b]{2}{*}{ n } & \multicolumn{3}{|l|}{ Total } & \multicolumn{4}{|l|}{ Pine } & \multicolumn{4}{|l|}{ Oak } & \multicolumn{4}{|c|}{ Other hardwood spp. } \\
\hline & & $\begin{array}{l}\text { \% canopy } \\
\text { cover }\end{array}$ & BA & Density & BA & Rel BA & Rel D & I.V. & BA & Rel BA & Rel D & I.V. & BA & Rel BA & Rel D & I.V. \\
\hline None & 28 & 36.4 & 3.69 & 633.9 & 0.77 & 20.82 & 5.36 & 13.49 & 2.90 & 78.67 & 92.86 & 83.84 & 0.02 & 0.51 & 1.79 & 2.67 \\
\hline GS-burn & 28 & 33.2 & 5.62 & 297.4 & 4.94 & 87.89 & 39.29 & 56.58 & 0.67 & 11.94 & 58.93 & 41.35 & 0.01 & 0.16 & 1.79 & 2.07 \\
\hline $\begin{array}{l}\text { GS-burn + } \\
\text { mechanical }\end{array}$ & 31 & 47.4 & 10.74 & 691.1 & 10.30 & 96.43 & 75.00 & 78.23 & 0.38 & 3.53 & 24.19 & 20.81 & $<0.01$ & 0.03 & 0.81 & 0.96 \\
\hline Young pine & 11 & 47.1 & 13.80 & 954.5 & 13.25 & 97.61 & 77.27 & 79.86 & 0.32 & 2.39 & 22.73 & 20.14 & 0.00 & 0.00 & 0.00 & 0.00 \\
\hline Mature pine & 20 & 47.5 & 9.53 & 590.3 & 9.13 & 95.86 & 73.75 & 77.37 & 0.39 & 4.09 & 25.00 & 21.15 & $<0.01$ & 0.05 & 1.25 & 1.48 \\
\hline Non-GS burn & 54 & 43.5 & 11.70 & 306.9 & 11.52 & 98.30 & 75.34 & 78.19 & 0.16 & 1.54 & 21.40 & 17.99 & 0.01 & 0.10 & 2.33 & 2.34 \\
\hline SB & 26 & 48.9 & 15.19 & 326.7 & 14.97 & 98.56 & 81.55 & 81.70 & 0.19 & 1.29 & 16.50 & 15.10 & 0.02 & 0.14 & 0.97 & 1.20 \\
\hline TB & 28 & 38.4 & 8.94 & 290.3 & 8.79 & 98.30 & 69.64 & 75.13 & 0.14 & 1.54 & 25.89 & 20.49 & 0.01 & 0.10 & 3.57 & 3.35 \\
\hline
\end{tabular}




\section{Comparison of Tortoise-selected Habitat Among Study Sites}

\section{Tree Data}

Percent canopy cover and other tree measurement data were similar among tortoise burrows from the different management prescriptions (Figure 6 through Figure 10), except where stand conditions limited the range of conditions available. For example, oak BA tended to be similar ( $<1 \mathrm{~m}^{2} /$ ha; Figure 10) among burrows from different study sites, except under 'no management' where tree density was much higher at random plots compared to other study sites (Figure 7). The 'no management' site (i.e., PSA) also had lower total BA and pine BA but higher oak BA (Figure 8 through Figure 10). Although tortoises at the 'no management' site seemed to be actively selecting burrow sites that were significantly different from the surrounding habitat (based on comparison of burrows and random sites), the range of conditions selected by tortoises at other sites were not available at under the 'no management' prescription.

Within the 'GS-burn + mechanical' site at Fort Gordon, canopy cover at burrows was similar in young and mature pine stands, but total BA, pine $\mathrm{BA}$, and tree density were higher at burrows in young pine stands relative to burrows in mature pine stands (Table 4). Under 'non-GS burn', canopy cover, tree density, total BA, and pine BA were significantly lower at tortoise-created burrows (TB) compared to starter burrows (SB) provided to tortoises at the beginning of the translocation project (Table 4), even though only starter burrows used by tortoises were included in the analysis.

\section{Herbaceous and Shrub Data}

Percent shrub cover at burrows was 20 to 25 percent at all study sites (Figure 11). Burrows in 'GS-burn' had significantly more wiregrass than at any other site (Figure 12), while burrows in Non-GS burn' had significantly more cover of other forbs than did other sites (Figure 15). However, the observed differences at burrows reflected differences in abundance in the available habitat. The only difference in herbaceous vegetation among burrows that does not appear to reflect abundance in available habitat is the high percent cover of other grasses at burrows under the 'no management' prescription (Figure 13). 
At the 'GS-burn + mechanical' site, percent cover of shrubs, wiregrass, and other grasses was higher at burrows in young pine stands than at burrows from mature pine stands. At the translocation site under 'non-GS burn', tortoise-created burrows had higher percent cover of shrubs and other grasses than did starter burrows. Although starter burrows had higher percent wiregrass cover than did tortoise-selected burrows, this is most likely due to the footprint of the wiregrass restoration project being confined to the area where starter burrows were constructed (Tuberville et al. in press).

Males Females

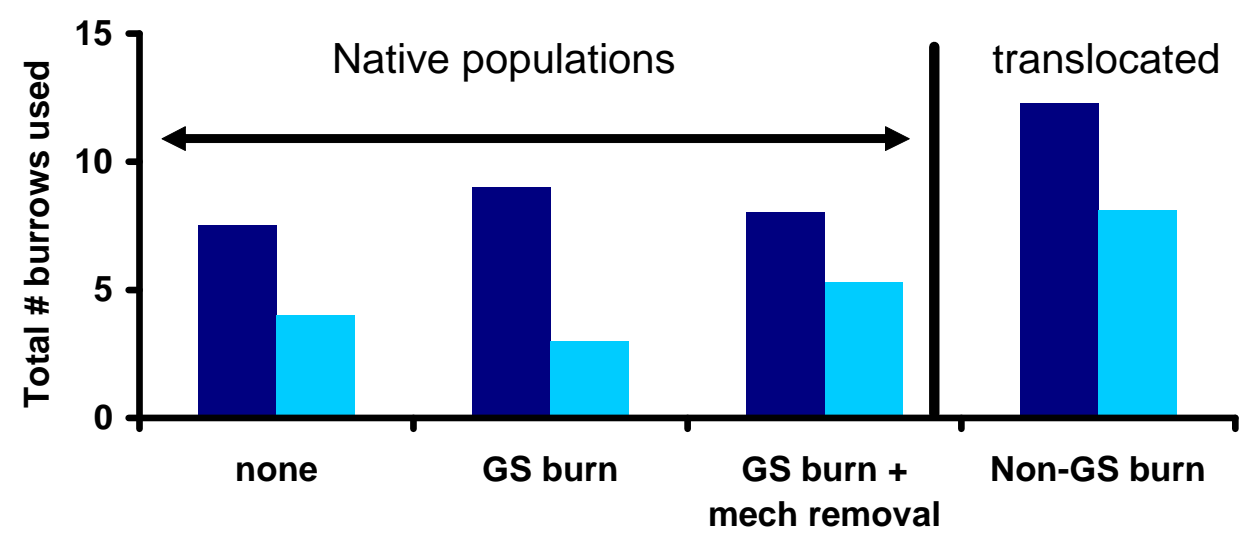

Management Prescription

Figure 17. Number of burrows used during the $2 \mathrm{yr}$ study period (2003-2004) by males and females under different forest management prescriptions.

\section{Summary of Major Findings}

- RCWs and gopher tortoises have similar (but not identical) habitat requirements that suggest that the two species can be managed simultaneously.

- Habitat varied significantly among the four management prescriptions. Differences were due primarily to canopy structure and composition (total, pine, and oak basal area). The 'no management' prescription (PSA site) was the most different from all other management prescriptions.

- The primary differences in herbaceous vegetation were the extremely high wire-grass cover at the 'GS-burn' site (TSR) and the low percent- 
age of legume cover at the 'no management' (PSA) and 'burn +mechanical' site (Fort Gordon).

- Tortoises selected burrow sites with 20 to 25 percent canopy, which was lower than the mean percent canopy available under all management prescriptions except 'GS-burn.' Under 'no management site,' tree density in the available habitat was extremely high and tortoises selected burrow sites with significantly lower tree density than in surrounding available habitat.

- Where the availability of legumes was limited (under 'no management site' and 'burn + mechanical'), tortoises used burrows that had significantly higher percent legume cover.

- Despite the differences in available habitat observed under the different management prescriptions, the burrows at those sites were remarkably similar to each other with respect to the vegetation parameters measured.

- Anecdotal observations made during the course of this project indicate that population demography may vary among the different management prescriptions, with juveniles and hatchlings being notably absent or scarce at the 'no management' (PSA) and 'GS-burn + mechanical' (Fort Gordon) sites. The potential effects of habitat management for RCWs on female reproductive success and juvenile recruitment in gopher tortoises should be examined. 


\section{Conclusions and Recommendations}

\section{Comparing These Results to Previous Studies}

Regardless of management prescription, tortoises generally selected burrow locations with 30 to 50 percent canopy cover, approximately 20 percent shrub cover, and lower basal area (total, pine, and oak) than in surrounding available habitat. Although it can be an important food item when other forage is not available (such as in the early growing season; Garner and Landers 1981), wiregrass abundance at burrows varied with management prescription but generally reflected its availability in the surrounding habitat. Under management prescriptions in which forage availability was limited, legumes - also considered to be an important food item (Garner and Landers 1981) -were significantly more abundant at burrow sites than in surrounding available habitat.

Habitat selection and space use by tortoises in this study may have been limited by the range of some habitat variables available for them to choose from (e.g., total herbaceous cover, tree density, etc). In addition, this study did not control for-nor do we fully understand - the potential legacy effects of previous land use and land management history. However, the fact that tortoises consistently selected sites with certain structural features (especially canopy measures) across a wide range in available habitats, suggests that specific management targets for tortoises can be developed. The reported values for canopy cover, as given above, are not surprising to anyone who has studied tortoise distribution even casually, but represent the first comprehensive reports of actual cover values across a wide variety of habitats and management practices. In addition, because these burrow site selection patterns were exhibited even by translocated tortoises, habitat manipulation -in combination with other release techniques-may prove to be a useful tool in promoting successful establishment of translocated gopher tortoises at their release site. Habitat assessment can also be used to screen potential release sites. It would appear that the site selected for release of the translocated animals did prove generally satisfactory in practice, as well as comparing well statistically with the measures for "tortoise selected" habitat which were derived 3 years after the original relocation project. 


\section{Determining Management Compatibility between Gopher Tortoise and RCW}

Obviously, RCWs and gopher tortoises do not always occur sympatrically. For example, RCWs can inhabit sites that are too mesic for gopher tortoises as long as the appropriate habitat structure is there (USFWS 2003). Likewise, gopher tortoises can thrive in areas that are not considered either nesting or foraging habitat for RCWs (e.g., treeless habitats, scrub lacking pine trees, and pine forests $\leq 30$ yrs old). However, there is broad overlap between types of macro- and micro-habitats that support both species and in the management prescriptions that are used to manage those habitats. Further, the matrix of available habitat may be complex, with many patches suitable for tortoises and not woodpeckers, or vice versa.

\section{Recommendations}

The general habitat guidelines provided in the recovery plans and recommended in the scientific literature are quire similar for both specieslonger timber rotation, lower stem density, frequent growing-season fire, replacement of offsite pines with native pines, etc. (Berish 2001, USFWS 2003, Wilson et al. 1997). For both species, growing-season fire is preferred over non-growing-season burns and use of mechanical or chemical hardwood control, which are recommended only for sites in need of intensive management or where growing-season fire is difficult or impossible to implement. However, gopher tortoises, because of their fossorial behavior and herbivorous diet, may be more susceptible than RCWs to the use of mechanical or chemical treatments (Cox et al. 1987, Wilson et al. 1997). Use of phenoxy or other broadleaf herbicides on herbaceous groundcover may be particularly damaging to the tortoise forage supply.

The specific management targets recommended for RCWs, especially those in the 2003 recovery plans, seem compatible with management of gopher tortoise populations. Further studies investigating the importance of legacy effects will help refine management targets so that these species can be managed simultaneously, particularly at sites in need of intensive management.

These studies were carried out at four sites close to the extreme northeastern limit of distribution of the gopher tortoise. It is not possible to be certain that the same measurements of preferable canopy cover will be uni- 
versal throughout the range of the tortoise, although it is reasonable to believe that the same general principles are applicable. Army installation forest and wildlife management planners should follow, where appropriate, understory and canopy management guidelines for the RCW until more specific modifications of these prescriptions are developed to specifically accommodate the gopher tortoises living in the same areas. For installations that do not manage for the RCW, but do have gopher tortoises, following the RCW management guidelines will provide good interim management criteria for responsible tortoise management. 


\section{References}

Aresco, M.J ., and C. Guyer. 1999. Burrow abandonment by gopher tortoises in slash pine plantations of the Conecuh National Forest. J ournal of Wildlife Management 63:26-35.

Auffenberg, W. and R. Franz. 1982. The status and distribution of the gopher tortoise (Gopherus polyphemus). Pp 95-126 in R.B. Bury (ed.) North American Tortoises: Conservation and Ecology. U.S. Fish and Wildlife Service, Wildlife Research Report 12, Washington, DC.

Auffenberg, W. and J. Iverson. 1979. Demography of terrestrial turtles. Pp 541-569 in M. Harless and N. Norlock (eds.) Turtles: Perspectives and research. WileyInternational, New York.

Berish, J .E. 2001. Management considerations for the gopher tortoise in Florida. Final Report. Florida Fish and Wildlife Conservation Commission, Tallahassee, Florida.

Boglioli, M.D., W.K. Michener, and C. Guyer. 2000. Habitat selection and modification by the gopher tortoise, Gopherus polyphemus, in Georgia longleaf pine forests. Chelonian Conservation and Biology 3:699-705.

Burke, R.L. and J . Cox. 1988. Evaluation and review of field techniques used to study and manage gopher tortoises. Pages 205-215 in Management of amphibians, reptiles, and small mammals in North America. RC. Szaro, K.E. Severson, and D.R. Patton (eds.). U.S. Department of Agriculture: Washington, DC.

Clark, E.E., R.N. Tsaliagos, and A.B. Pittman. 2001. Gopherus polyphemus distribution. Herpetological Review 32:191.

Clark, E.E. 2003. Relocation and population modeling for gopher tortoise recovery. M.S. Thesis. University of Georgia, Athens, Georgia.

Coker, J.W. and T.M. Murphy. 1993. Tillman Sand Ridge Heritage Preserve Management Plan. Unpublished report. South Carolina Department of Natural Resources, Columbia, SC.

Cox, J ., D. Inkley, and R. Kautz. 1987. Ecology and habitat protection needs of gopher tortoise (Gopherus polyphemus) populations found on lands slated for largescale development in Florida. Nongame Wildlife Program Technical Report No. 4. Florida Game and Fresh Water Fish Commission, Tallahassee, Florida.

Diemer, J .E. 1992a. Home range and movement patterns of the tortoise Gopherus polyphemus in northern Florida. J ournal of Herpetology 26:158-165.

Diemer, J.E. 1992b. Demography of the tortoise Gopherus polyphemus in northern Florida. J ournal of Herpetology 26:281-289. 
Dozier, J ., and J . Stowe. 1999. Tillman Sand Ridge Heritage Preserve Management Plan. Unpublished report. South Carolina Department of Natural Resources, Columbia, SC.

Eubanks, J.O., W.K. Michener, and C. Guyer. 2003. Patterns of movement and burrow use in a population of gopher tortoises (Gopherus polyphemus). Herpetologica 59:311-321.

Garner, J .H., and J .L. Landers. 1981. Foods and habitats of the gopher tortoise in southwestern Georgia. Proc. Ann. Conf. S.E. Association of Fish and Wildl. Agencies 35:120-133.

Germano, D.J . and R.B. Bury. 1994. Research on North American tortoises: a critique with suggestions for the future. Pages 187-204 in R.B. Bury and D.J . Germano (eds.) Biology of North American tortoises. U.S. Fish and Wildlife Service, Washington, DC.

Gibbons, J.W. 1990. Turtle studies at SREL: a research perspective. Pp. 19-44 in: Life history and ecology of the slider turtle. J.W. Gibbons (ed.). Washington, DC: Smithsonian Institution Press.

Guyer, C. and S.M. Hermann. 1997. Patterns of size and longevity of gopher tortoise (Gopherus polyphemus) burrows: implications for the longleaf pine ecosystem. Chelonian Conservation and Biology 2:507-513.

Hermann, S.M., C. Guyer, J.H. Waddle, and M.G. Nelms. 2002. Sampling on private property to evaluate population status and effects of land use practices on the gopher tortoise, Gopherus polyphemus. Biological Conservation 108: 289-298.

Iverson, J .B. 1980. The reproductive biology of Gopherus polyphemus (Chelonia: Testudinidae). American Midland Naturalist 103:353-359.

Landers, J .L., J .A. Garner, and W.A. McRae. 1980. Reproduction of gopher tortoises (Gopherus polyphemus) in southwestern Georgia. Herpetologica 36:353-361.

MacDonald, L.A., and H.R. Mushinsky. 1988. Foraging ecology of the gopher tortoise, Gopherus polyphemus, in a sandhill habitat. Herpetologica 44:345-353.

McRae, W.A., J.L. Landers, and J .A. Garner. 1981. Movement patterns and home range of the gopher tortoise. American Midland Naturalist 106:165-179.

Noss, R.F., E.T. LaRoe III, and J .M. Scott. 1995. Endangered ecosystems of the United States: a preliminary assessment of loss and degradation. U.S. Department of the Interior, National Biological Service, Washington, DC.

Save Our Big Scrub, Inc. and Wild South. 2006. Petition to list the eastern population of the gopher tortoise as a threatened species. Received J anuary 20, 2006. Before the Secretary of the US Interior and the Director of the USFWS.

Smith, L.L., T.D. Tuberville, and R.A. Seigel. In press. Workshop on the ecology, status, and management of the gopher tortoise (Gopherus polyphemus), J oseph W. J ones Ecological Research Center, Newton, GA, 16-17J anuary 2003: Final results and recommendations. Chelonian Conservation and Biology. 
Smith, R.B., D.R. Breininger, and V.L. Larson. 1997. Home range characteristics of radiotagged gopher tortoises on Kennedy Space Center, Florida. Chelonian Conservation and Biology 2:358-362.

Tuberville, T.D. 1998. Effects of soil disturbance by gopher tortoises (Gopherus polyphemus) on vegetation structure and composition in a pine-oak sandhills community. M.S. Thesis, University of Georgia, Athens, GA. 94 p.

Tuberville, T.D., E.E. Clark, K.A. Buhlmann, and J.W. Gibbons. 2005. Translocation as a conservation tool: site fidelity and movement of repatriated gopher tortoises (Gopherus polyphemus). Animal Conservation. Animal Conservation 2005(8): 349-358.

Tuberville, T.D., and M.E. Dorcas. 2001. Winter survey of a gopher tortoise population in South Carolina. Chelonian Conservation and Biology 4:182-186.

U.S. Department of Agriculture. 1980. Soil survey of Beaufort and J asper counties, South Carolina. 179 pp., illus.

USFWS 1970. Red-cockaded Woodpecker listed as an endangered species. Federal Register 35:16047.

USFWS. 1987. Endangered and threatened wildlife and plants; determination of threatened status for the gopher tortoise (Gopherus polyphemus). Federal Register 52: 25376-25380.

USFWS. 1990. Gopher tortoise recovery plan. U.S. Fish and Wildlife Service, J ackson, Mississippi. 28 pp.

USFWS. 2003. Recovery plan for the red-cockaded woodpecker (Picoides borealis): second revision. U.S. Fish and Wildlife Service, Atlanta, GA. 296 pp.

White, D.L., and K.F. Gaines. 2000. The Savannah River Site: site description, land use and management history. Studies in Avian Biology 21:8-17.

Wilson, D.S., H.R. Mushinsky, and R.A. Fischer. 1997. Species profile: gopher tortoise (Gopherus polyphemus) on military installations in the southeastern United States. Technical Report SERDP-97-10, U.S. Army Engineers Waterways Experiment Station, Vicksburg, MS.

Wright, J.S. 1982. Distribution and population biology of the gopher tortoise, Gopherus polyphemus, in South Carolina. M.S. Thesis, Clemson University, Clemson, SC. 


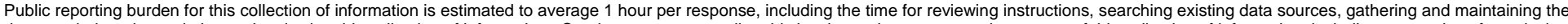

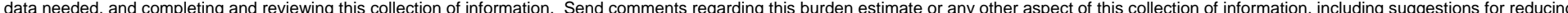

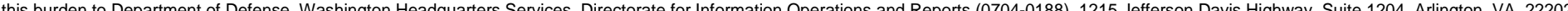

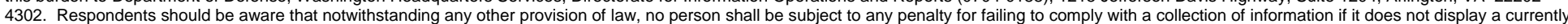
valid OMB control number. PLEASE DO NOT RETURN YOUR FORM TO THE ABOVE ADDRESS

\section{REPORT DATE (DD-MM-YYYY) \\ March 2007 \\ Final}

4. TITLE AND SUBTITLE

Habitat Selection by the Gopher Tortoise (Gopherus polyphemus)

3. DATES COVERED (From - To)

5a. CONTRACT NUMBER

5b. GRANT NUMBER

5c. PROGRAM ELEMENT NUMBER

5d. PROJECT NUMBER

A896

5e. TASK NUMBER

CNN-T063

5f. WORK UNIT NUMBER

8. PERFORMING ORGANIZATION REPORT NUMBER

ERDC/CERL TR-07-1

U.S. Army Engineer Research and Development Center (ERDC)

Construction Engineering Research Laboratory (CERL)

PO Box 9005

Champaign, IL 61826-9005

\section{SPONSORING I MONITORING AGENCY NAME(S) AND ADDRESS(ES)}

10. SPONSOR/MONITOR'S ACRONYM(S)

U.S. Army Corps of Engineers

Office of the Director of Environmental Programs

c/o Humphrey’s Engineering Center

7701 Telegraph Road

Alewxandria, VA 23315-3860

11. SPONSOR/MONITOR'S REPORT NUMBER(S)

\section{DISTRIBUTION / AVAILABILITY STATEMENT}

Approved for public release; distribution is unlimited.

\section{SUPPLEMENTARY NOTES}

Copies are available from the National Technical Information Service, 5285 Port Royal Road, Springfield, VA 22161.

\section{ABSTRACT}

The gopher tortoise (Gopherus polyphemus) occurs in the southeastern Coastal Plain and has experienced widespread decline due to habitat loss and other human impacts. The largest remaining populations occur on private lands and military installations. Proper management at these sites will be critical to the success of the species. The goal of this study was to determine the response of gopher tortoises to forestry management practices commonly implemented in the management of the red-cockaded woodpecker. We monitored habitat use of individual tortoises at four study sites with different ownership and management scenarios: Fort Gordon (military installation, winter burning), Savannah River Site (federal defense facility, winter burning, translocated population), Tillman Sand Ridge (state wildlife preserve, summer burning), and a private hunting preserve (no management). Habitat data were collected to characterize typical canopy and herbaceous vegetation of each site. Data were collected at active burrows; the anecdotal belief that tortoises select the most open habitat available was confirmed. The preferred habitat density appears to be in the range of 40 percent canopy cover, a value compatible with current woodpecker management guidelines. Results will be used to develop recommendations for the concurrent management of gopher tortoises and red-cockaded woodpeckers.

\section{SUBJECT TERMS}

gopher tortoise

environmental management

\section{SECURITY CLASSIFICATION OF:}

\section{a. REPORT}

Unclassified

\section{b. ABSTRACT} Unclassified
Gopherus polyphemus

habitat

threatened, endangered, and sensitive species (TES) 